\title{
888-444 Ma Global Plate Tectonic Reconstruction With Emphasis on the Formation of Gondwana
}

\author{
Christian Vérard * \\ Department of Earth Sciences, University of Geneva (UNIGE), Geneva, Switzerland
}

OPEN ACCESS

Edited by:

Guillermo Booth-Rea, University of Granada, Spain

Reviewed by:

Sebastian Oriolo, Consejo Nacional de Investigaciones Científicas y Técnicas (CONICET),

Argentina

Damien Delvaux,

Royal Museum for Central Africa,

Belgium

*Correspondence:

Christian Vérard

Christian.verard@unige.ch

Specialty section:

This article was submitted to Structural Geology and Tectonics,

a section of the journal

Frontiers in Earth Science

Received: 09 February 2021

Accepted: 07 May 2021

Published: 28 May 2021

Citation:

Vérard C (2021) 888-444 Ma Global Plate Tectonic Reconstruction With Emphasis on the Formation of Gondwana.

Front. Earth Sci. 9:666153. doi: 10.3389/feart.2021.666153
The formation of Gondwana results from a complex history, which can be linked to many orogenic sutures. The sutures have often been gathered in the literature under broad orogenies - in particular the Eastern and Western Pan-African Orogenies - although their ages may vary a lot within those wide belts. The PANALESIS model is a plate tectonic model, which aims at reconstructing $100 \%$ of the Earth's surface, and proposes a geologically, geometrically, kinematically, and geodynamically coherent solution for the evolution of the Earth from 888 to $444 \mathrm{Ma}$. Although the model confirms that the assembly of Gondwana can be considered complete after the Damara and Kuunga orogenies, it shows above all that the detachment and amalgamation of "terranes" is a roughly continuous process, which even persisted after the Early Cambrian. By using the wealth of Plate Tectonics, the PANALESIS model makes it possible to derive numerous additional data and maps, such as the age of the sea-floor everywhere on the planet at every time slice, for instance. The evolution of accretion rates at mid-oceanic ridges and subduction rates at trenches are shown here, and yields results consistent with previous estimates. Understanding the variation of the global tectonic activity of our planet through time is key to link plate tectonic modeling with other disciplines of Earth sciences.

Keywords: panalesis, plate tectonic model, Gondwana, neoproterozoic, Cambrian, Ordovician, pan-african orogenies

\section{INTRODUCTION}

\section{The panalesis Model}

The formation of Gondwana encompassed many regional and distinct geological histories that occurred during the Neoproterozoic - Early Palæozoic. It implies that the geological records in some areas may be relatively rare (with almost no fossil record) and, to some extent, questionable, in particular in terms of age and position.

However, a solution for the formation of Gondwana is proposed herein in the framework of the PANALESIS model (Vérard, 2019a; Vérard, 2019b). PANALESIS is a global plate tectonic model (constructed under ArcGIS ${ }^{\circledR}$ ) using the methodology developed at the University of Lausanne (UNIL; Vérard et al., 2015a; Vérard et al., 2015b; see also Hochard, 2008), but entirely redeveloped from scratch and for which the starting point is arbitrarily chosen at $888 \mathrm{Ma}$. In order to transfer data from present-day back to past configurations, PANALESIS uses, like other models, "tectonic elements" (hereafter named TE; Vérard, 2019a), i.e., "puzzle pieces" of the Earth's surface (Figure 1; Tectonic plates and Tectonic Elements section). However, the reconstruction method 

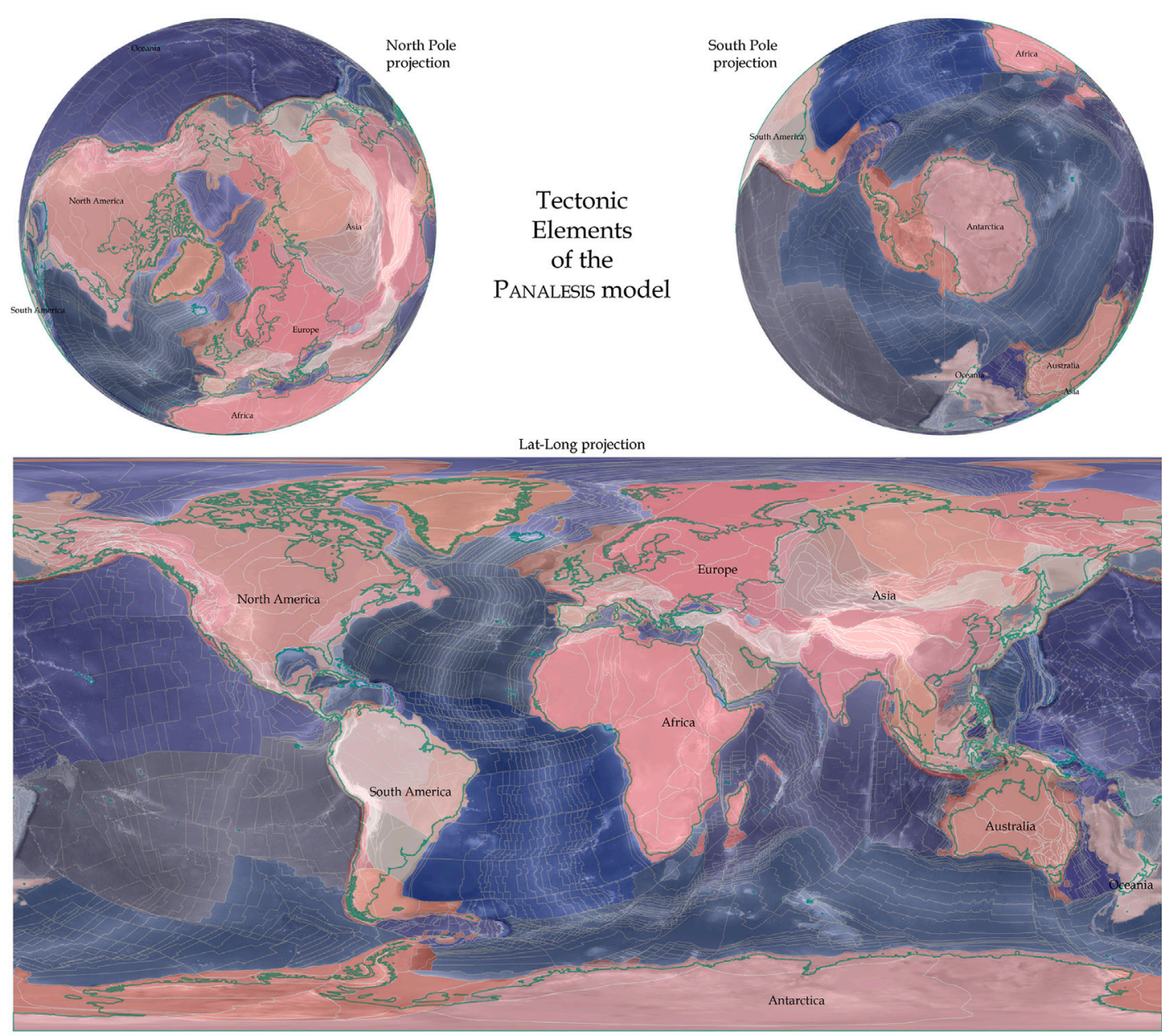

FIGURE 1 | "Tectonic elements" (TES) of the PANALESIS model grouped in different domains.

primarily relies on the "dynamic plate boundaries" and "synthetic isochrons" techniques (Stampfli and Borel, 2002) and on the inheritance from one reconstruction to the next (see "dual control approach"; Hochard, 2008; Vérard, 2019b). Because of these specific methods, the starting point of the model includes speculative hypotheses, and the model is not strongly constrained as long as gaps remain in the plate tectonic coverage (i.e., $<100 \%$ of the Earth's surface coverage). For further details about the methodology, the reader shall refer to (Vérard, 2019a; Vérard, 2019b) and the references therein.

Nevertheless, the model is geologically, geometrically, kinematically, and geodynamically coherent and attempt at using and reconciling all available data (known by the modeler). The retained solution is presented herein in the form of tectonic maps. Because the reconstructions are made at global scale, one cannot expect a resolution better than about $1^{\circ}$ (approximately $100 \mathrm{~km}$ ), and local geological aspects might be poorly defined. However, the goal is to retrieve the global tectonic scheme and reconstructions have been determined every $10 \mathrm{Ma}$ from $888 \mathrm{Ma}$ (and $880-450 \mathrm{Ma}$ ) to $444 \mathrm{Ma}$. The second part of the model $(444-000 \mathrm{Ma})$ is still under development and will be released soon. Note that all maps and associated data are available upon request. The starting age of $888 \mathrm{Ma}$ was chosen for fun in a time interval between 850 and $900 \mathrm{Ma}$, which corresponds to the dislocation of Rodinia, and ends at $444 \mathrm{Ma}$ (Hirnantian; i.e., at the boundary between Ordovician and Silurian), halfway from reconstructions until present-day.

Although it is stressed here again that a plate tectonic model cannot be reduced to a set of Euler poles (see Vérard, 2019a; Vérard, 2019b; but see also; Vérard et al., 2012), an animation (in Central Africa fixed reference; see Supplementary Material S1) and associated Euler poles are provided in supplementary material accompanying the present paper (Supplementary Material S2). All maps are presented herein in Africa (Congo TE) fixed reference frame because the paper focuses on the formation of Gondwana. It is more convenient to see how the different elements move around the core of Gondwana and 
eventually amalgamated. The palæomagnetic reference frame is consequently shown as a moving grid on top of the maps.

\section{Tectonic Plates and Tectonic Elements}

Tectonic plates are (lithospheric) fragments of the Earth's surface, bounded by plate tectonic boundaries (such as mid-oceanic ridges, subduction zones, etc.). Tectonic elements (TEs, named so in Vérard, 2019b after Ross and Scotese, 1988; instead of the controversial terms of "blocks," "terranes," "GDUs," "plates," etc. used elsewhere) are "puzzle pieces" of the Earth's surface used to carry information from present to past. They are specific to a given model, although they are delimited on the basis of geological evidences (in theory more or less common to all models; compare for instance Stampfli and Borel, 2002; Scotese, 2009; Seton et al., 2012; Stampfli et al., 2013; Domeier and Torsvik, 2014; Scotese, 2016; Merdith et al., 2017) and suggest a common, coherent evolution of every TE through time. The TEs are carried by the tectonic plates but are not tectonic plates. TEs are defined as coherent pieces (i.e., a single Euler pole would describe their movement) of continental or oceanic lithosphere of a priori any size (Figure 1). However, the further we go back in time, the smaller and numerous the TEs in the model. Moreover, TEs are delimited as they are in the present-day world. Consequently, geological bending, stretching or shortening is not corrected within a TE, but deformation is assessed and applied to tectonic plates, and tight (untight) fits between TEs are used estimate crustal extension (shortening) at tectonic plate boundaries.

The names of the TEs are usually defined according to local geology names (e.g., Superior TE in North America, VentuariTapajos TE in South America, Dharwar TE in India). On the other hand, the names of tectonic plates can stem from the literature (e.g., Rodinia plate, Gondwana plate, Laurentia plate), from one of the major TE carried by that plate (e.g., the Napier plate carries the Napier TE among others), or from a name arbitrarily chosen by the modeler. The latter names often concern purely oceanic plates, and a name of water deities (e.g., the Idliragijenget plate, after Idliragijenget, the god of the ocean in Inuit mythology) is usually chosen in the tradition of ocean and plate naming in global reconstructions (e.g., Tethys, Iapetus). It is considered in the PANALESIS model that a tectonic plate can come into existence only once. This is why, for example, most of the TEs from India are carried by the Napier plate (and later by the Gondwana plate) in the reconstructions shown here, because the name "India plate" will be used for the Mesozoic migration of the Indian sub-continent.

Note also that it is possible a plate is named after one TE it carries (e.g., Iskel plate), but when that element collides with a passive margin for instance, the element is amalgamated to the continent, the passive margin is inverted, and the remaining oceanic area of that plate (e.g., Iskel plate) starts being consumed in the subduction zone. The name of the plate is kept (e.g., Iskel plate) although the TE (e.g., Iskel TE) is not carried by that plate anymore.

All names for tectonic plates are not necessarily mentioned in the text here, but are provided in supplementary material (Supplementary Material S2). In addition, over 1,200 rotation parameters are given (Supplementary Material S2) for every tectonic plate for the reconstructions from 888 to $444 \mathrm{Ma}$. Rotation parameters for TEs, however, are only given for the reconstruction (fit) at $888 \mathrm{Ma}$ (Supplementary Material S2).

\section{The Apparent Polar Wander Path for PANALESIS}

Because the focus of the paper bears upon the formation of Gondwana, it has been chosen to present the reconstructions in Central Africa (Congo) fixed reference frame, so that all elements move around the heart of Gondwana. The palæomagnetic reference frame, therefore, is shown as a moving grid.

The definition of the apparent polar wander (APW) path for Gondwana is a long-standing matter of debate (e.g., Vérard, 2004 and references therein). However, Torsvik et al. (2012) published a comprehensive and convincing synthesis of palæomagnetic data (see their Table 1) for the Phanerozoic. If they agree with large segments of that path, Stampfli et al. (2013); and Scotese and Elling (2017) in particular, questioned the interpretation of Torsvik et al. (2012) concerning the effects of True Polar Wander and/or flattening factor, and rather favor a loop in the APW path between say $\sim 120$ and $\sim 220 \mathrm{Ma}$ (Figure 2). Moreover, the palæomagnetic data older than the Carboniferous also display large discrepancies. Stampfli et al. (2013) therefore suggested to constrain their APW path using palæoclimatic indicators (such as glacial deposits for instance) and noticed the good correspondence between the changes in the trend of their APW path and major tectonic events affecting Gondwana (e.g., opening of the PalæoTethys; see Figure 5 of Stampfli et al., 2013). PANALESIS largely follows those conclusions. For older times, the definition of a probative APW path is even more difficult to establish. Note, however, that if the APW path needs to be modified a bit in the future, the geologic, geometric, kinematic, and geodynamic relationships from plate to plate shall be kept, and consequently the model should not be fundamentally modified.

Therefore, it has been decided to tentatively define the APW path for PANALESIS from 1,250 to $000 \mathrm{Ma}$ after the data already published in Tohver et al. (2006); Li et al. (2008); Swanson-Hysell et al. (2012); Torsvik et al. (2012); Stampfli et al. (2013); and Scotese and Elling (2017). A spline-smoothing technique has been applied to derive an APW path with poles defined every 5 million years, a path which is provided as table (Supplementary Material S2) and shown in Figure 2.

\section{Structure of the Manuscript}

After some preliminary remarks on Rodinia, the paper is structured as follows: 1) the location, extension and timing of all pan-African sutures are briefly summarized in order to recall the existing constraints on the end-point of the reconstructions at $444 \mathrm{Ma}$; 2) the fit for Rodinia at $888 \mathrm{Ma}$ is equally briefly described in order to argue for the startingpoint of the reconstructions; 3 ) the main aspects of the evolution of the plate tectonic reconstructions from 888 to $444 \mathrm{Ma}$ are then presented; 4) the implications of the plate 


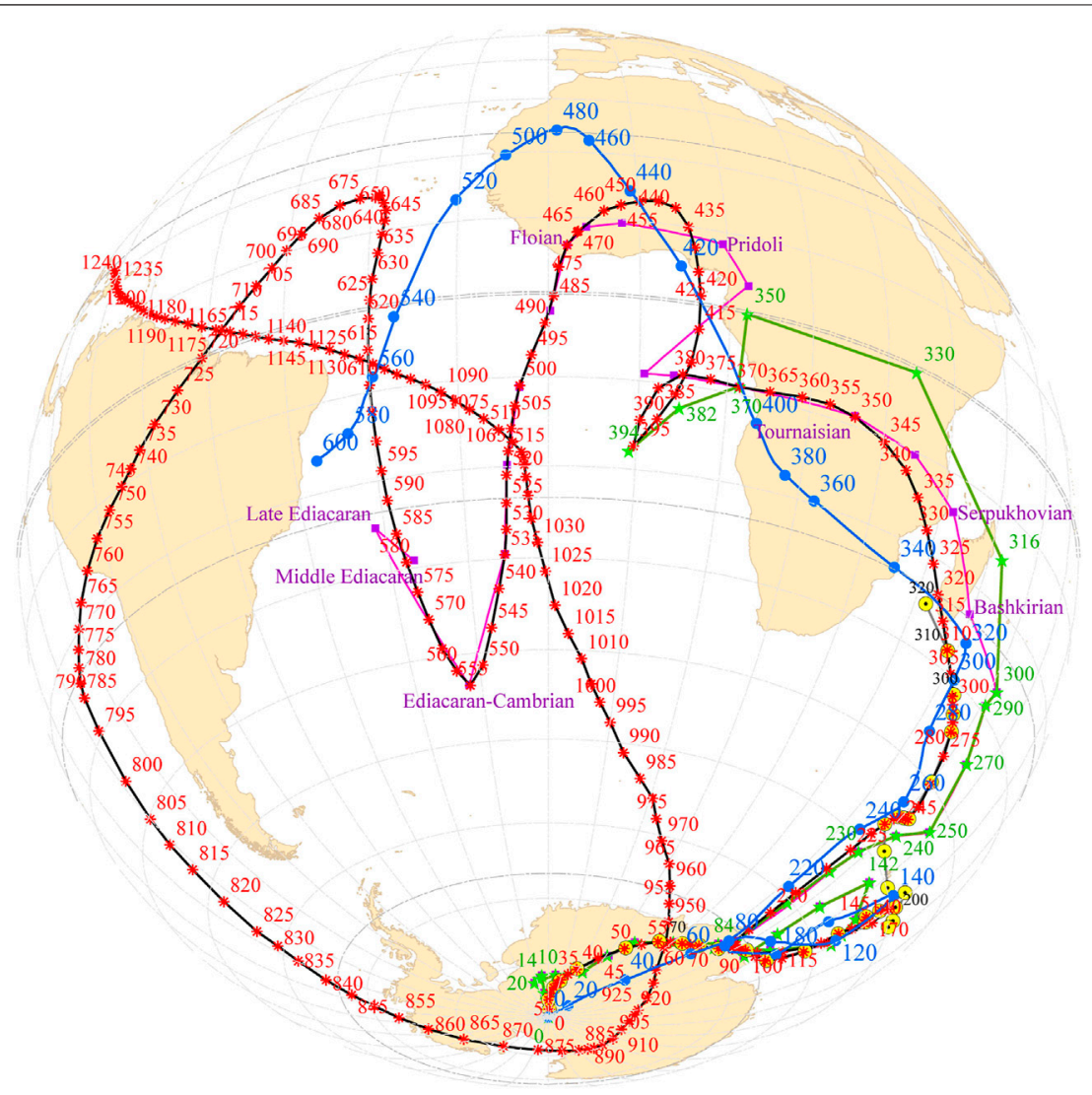

FIGURE 2 | Apparent polar wander (APW) path for central Africa (Congo TE) after the PANALESIs model (black curve with red stars). Also shown for comparison, the APW paths after (Scotese and Elling, 2017; blue line and dots), after (Hochard, 2008; purple line and squares), after (Stampfli et al., 2013; green line and stars), after (Torsvik et al., 2012; gray line and yellow circles); see also Supplementary Material S2. Orthogonal projection centered at $010^{\circ} \mathrm{W} / 30^{\circ} \mathrm{S}$.

tectonic model is discussed in terms of variation of the ages of the sea-floor through time and in term of accretion and subduction rates - in other words, in terms of tectonic activity - from the Tonian (Neoproterozoic) to the Ordovician (early Palæozoic).

Note also that, because the PANELESIS model contains 2550 TEs (Figure 1), the description of the tectonic evolution of each of them over such a long duration would certainly need a book. The present paper is therefore a general overview of what the PANALESIS model does and treats.

\section{RODINIA OR PANNOTIA? PRELIMINARY REMARKS}

Many authors agree to suggest that a supercontinent existed at approximately $900 \mathrm{Ma}$ (e.g., Bogdanova et al., 2009), and broke up in several stages thereafter. The corresponding supercontinent is commonly termed "Rodinia." The name Rodinia, however, was first propounded by (McMenamin and McMenamin, 1990); but see also (Valentine and Moore, 1970; Dewey and Burke, 1973; or Piper, 1976) to take into account the fact that many continental fragments assembled during collisions around $1.1 \mathrm{Ga}$ (see also
Meert, 2012). However, the name Rodinia has been used since the 1990 s to refer to a wide variety of Neoproterozoic supercontinental reconstructions (e.g., Powell, 1995; Young, 1995; Torsvik et al., 1996; Dalziel, 1997; Weil et al., 1998; Condie, 2003; Meert and Torsvik, 2003; Goodge et al., 2008; Li et al., 2008; Scotese, 2009; Piper, 2010; Nance et al., 2014; Evans et al., 2016; Merdith et al., 2017), potentially not reflecting the same supercontinent at the same age. Notice that if a supercontinent formed at ca. 1.1-1.2 Ga, one can wonder if and how it was maintained as one piece over 200 to 400 millions of years (from $1.2-1.1 \mathrm{Ga}$ to $900-800 \mathrm{Ma}$ ). In other words, could Pangæa still exist today? (see discussion in Yoshida and Santosh, 2011 for example).

In the literature, however, it has been questioned whether the supercontinent with age around 850-900 Ma should not be named Pannotia (as first proposed by Stump, 1987) and the term Rodinia reserved to an older, $c a .1 \mathrm{Ga}$, supercontinent. The debate on the existence of Pannotia has just been revived recently for example by Nance and Murphy (2018) or Kroner et al. (2020) and in particular Murphy et al. (2020). Keeping this issue in mind, however, the present study uses the widely accepted term Rodinia, but reserves the possibility to change the name when reconstructions back to $1 \mathrm{Ga}$ or more will be made. 


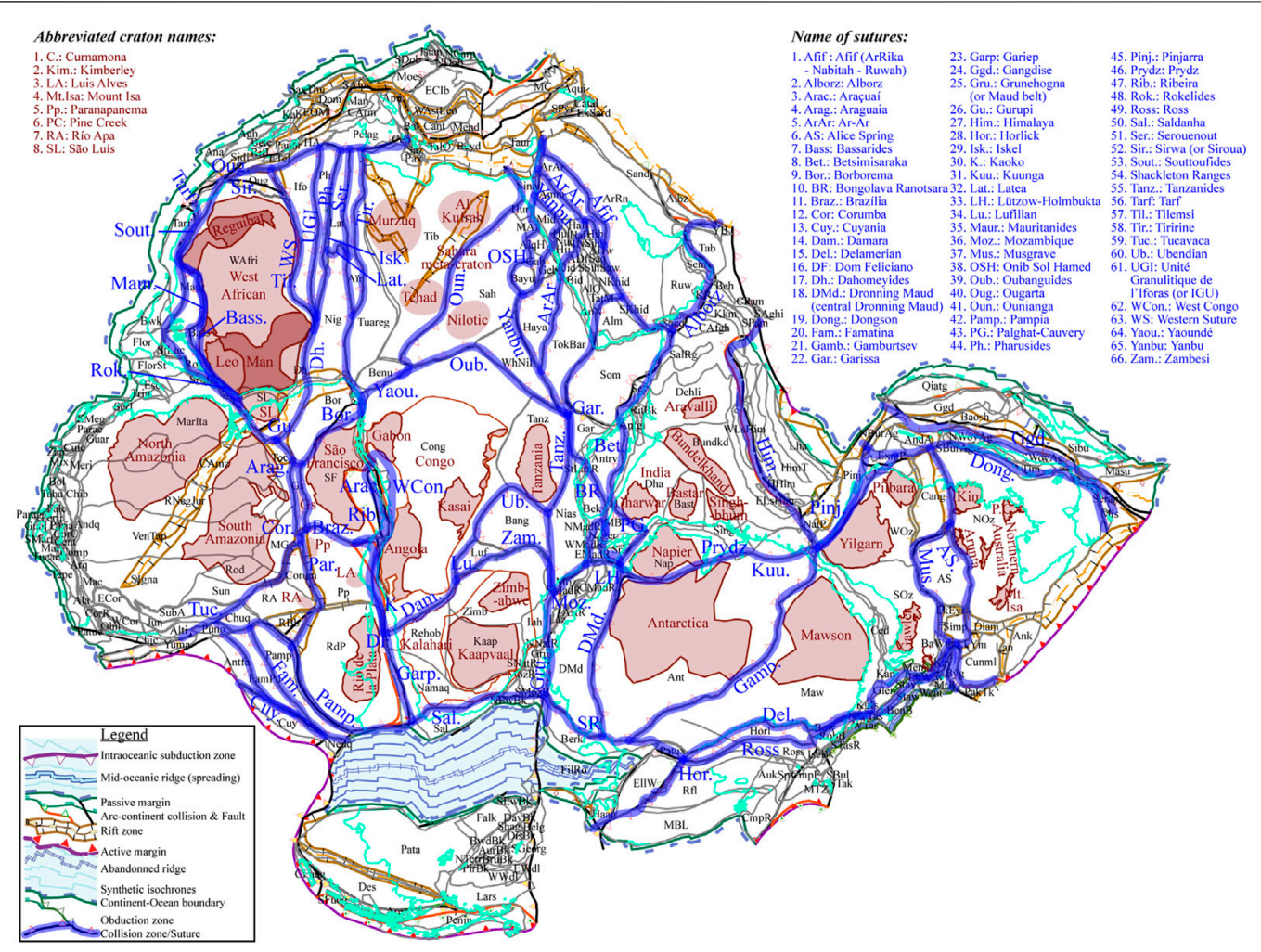

FIGURE 3 | Map of the main sutures (blue) of Gondwana, modified after Stampfli et al. (2013). The configuration of Gondwana is shown at 444 Ma, as per Figure 8P. (i.e., at the end of the evolution from 888 to $444 \mathrm{Ma}$ ); Cratonic areas are shown in brown; see also Supplementary Material S2.

\section{THE "BRASILIANO - PAN-AFRICAN" COLLISIONS}

A number of sutures correspond to the remnants of collisions that led to the formation of Gondwana. Those features are key and definite evidence of the amalgamation of Gondwana. Those sutures are listed hereafter with some key characteristics. A synthetic map has been proposed by Stampfli et al. (2013) and used as basis for the map shown in Figure 3, which displays their spatial extension.

Note that the term "pan-African" has first been proposed by Kennedy (1964) and has later been extended to Gondwana, although some want to distinguish the Brasiliano collisions (South American) from the pan-African (mainly African Arabian) collisions of Gondwana. Each of the Brasiliano pan-African collisions shown herein boils down to a main single line although the internal structures of the collision areas are often wider and much more complex than they may appear.

\section{The Arabian - Nubian Collisions}

Stern and Johnson (2010) and Johnson et al. (2011), in particular, but also Fritz et al. (2013), showed the complex nature of the terrains around the Arabian and Nubian shields. Amalgamation ages range from 720 to $680 \mathrm{Ma}$, with post-almagamation events (see also Johnson and Woldehaimanot, 2003; Cox et al., 2012).
Collisional events, gathered under the term Yanbu suture (Figure 4), are centered around $720 \mathrm{Ma}$, whereas those along the Ar-Ar sutures are younger, around 710-700 Ma. The structures related to the Onib Sol Hamed suture are interpreted as the expression of the closure of a back-arc basin around 700-680 Ma.

Tectono-metamorphic events along the Garissa suture are much younger and centered around $640 \mathrm{Ma}$ (e.g., Sommer et al., 2005). The age coincides also with the peak of activation of the Afif suture that comprises the ArRika and Ruwah faults and the Nabitah belt (Johnson et al., 2011).

Many sutures and faults, such as the Keraf fault zone and the ArRika fault zone, are reactivated around $600 \mathrm{Ma}$. The Alborz collisional event with age centered around 605-590 Ma, in particular, is interpreted as responsible for those reactivations (Le Métour et al., 1995).

\section{The Saharan and Central African Collisions}

The tectonic evolution of the central-western Hoggar area has been summarized by Caby (2003). This author has stated that the UGI suture (Figure 4) is a structure resulting from a double-sided subduction process that probably ended around 620-610 Ma. To the west, the Western Suture separates the Iforas from the West African craton. To the east, the UGI suture is actually somewhat disconnected from the Pharusian terrane by the Adrar fault which is interpreted to 


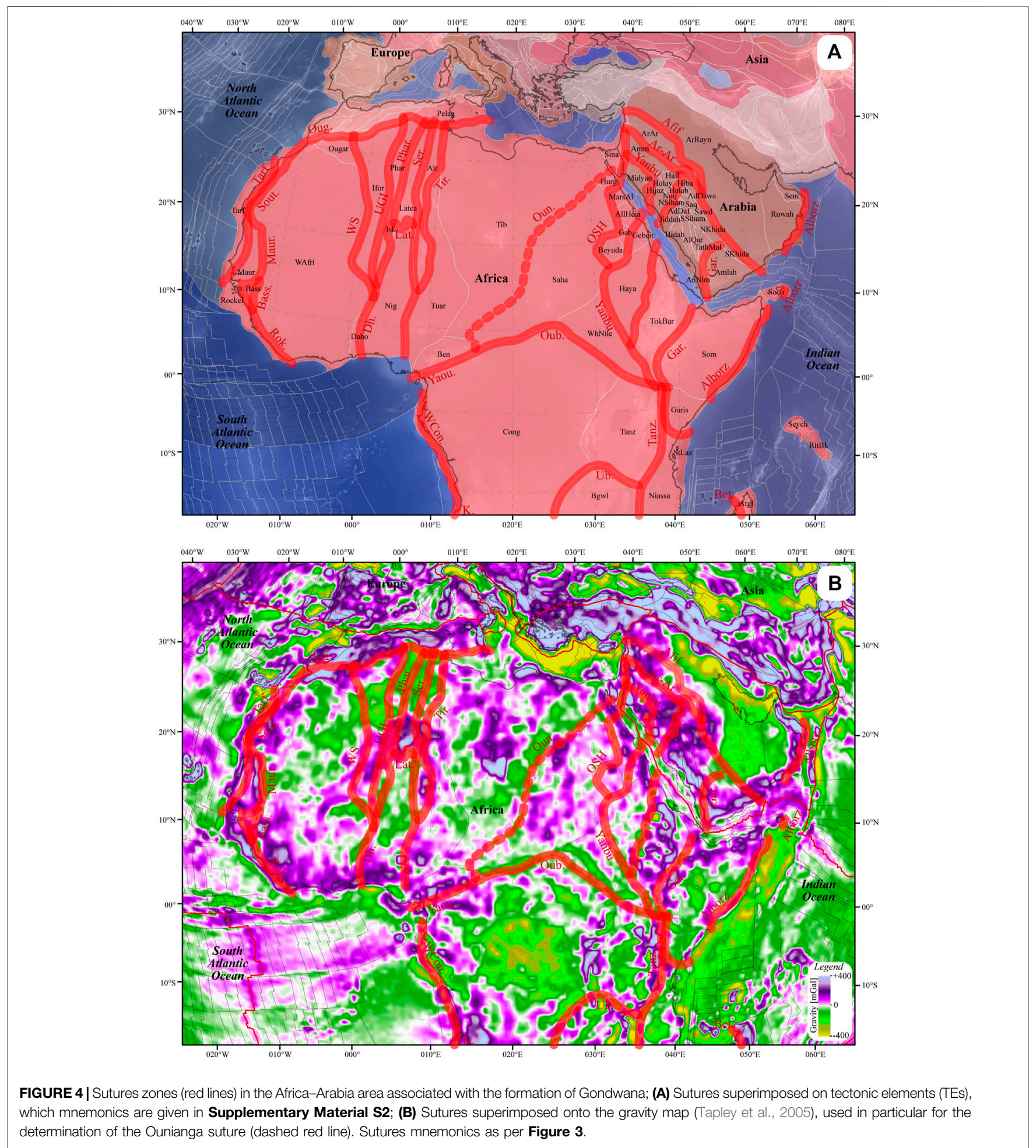

be activated with late Gondwana amalgamation events (i.e., West Congo belt, see below), but also during the Mesozoic break-up of Gondwana (e.g., Moulin, 2003). The Pharusian terrane docked to the east against the Iskel basement, which is itself separated from what Liégeois et al. (2003) named LATEA, and is included herein in the Tibestan TE.
The collision between the Iskel and LATEA (Tibestan) terranes (TEs) is interpreted to occur at around $680 \mathrm{Ma}$.

In Central Africa, the Oubanguides form a long suture that cross-cut the African continent. The age of the collisional peak metamorphism is set around 620-600 Ma (Ouabego-Kourtene, 2013 and references therein). 


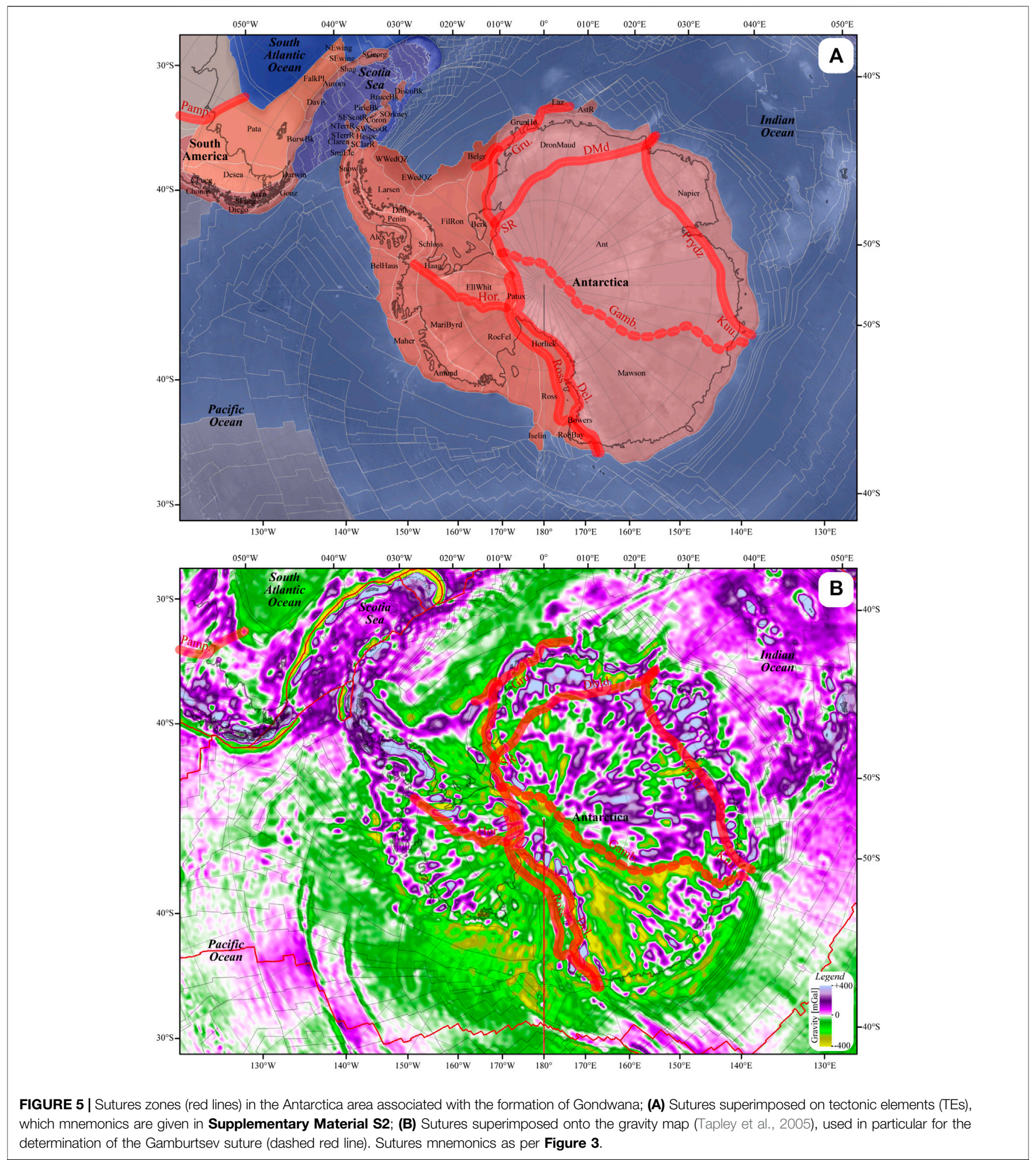

The Saharan desert area has often been described as a "metacraton" (e.g., Condie, 1992 and references therein). However, according to structural features (seismic waves analysis, Abdelsalam et al., 2011; "rheological domains," Liégeois et al., 2013), ages (Abdelsalam et al., 2002), and in particular, according to gravity anomalies (Tapley et al., 2005; Figure 4), a suture, with age around $740 \mathrm{Ma}$ (see $770-740 \mathrm{Ma}$ section), is tentatively drawn along the Ounianga line (name created after the Ati-Ounianga "positive gravimetric anomaly" of Louis, 1970; see also Liégeois et al., 1994; Poudjom-Djomani, 1994; Liégeois et al., 2003; Isseini, 2011). 


\section{The West African Collisions}

Different main sutures run along the west side of the West African craton.

One is the Mauritanides - Tarf (Figure 3), which main activity phase, around 320 to $280 \mathrm{Ma}$, is related to the formation of Pangæa (Villeneuve, 2005; Stampfli et al., 2013). Among the series of the Mauritanides, however, the "séries pourprées" in particular, recorded the "Pan-African II tectonic event" between 550 and $500 \mathrm{Ma}$ (Villeneuve, 2005) related to the formation of Gondwana (Caby and Kienast, 2009).

To the south, the Rokelides, 530-500 Ma (Williams and Culver, 1982; Villeneuve, 2005; Villeneuve et al., 2010), extend to the south of the São Luís Craton in South America.

Those two collision belts, the Mauritanides and Rokelides, largely conceal the Bassarides, a collisional event centered around 650-630 Ma (Villeneuve, 2005; Caby and Kienast, 2009).

Finally, to the north, the West African craton is bounded by the Ougarta Ranges (Gasquet et al., 2005; Ghienne et al., 2007; Ennih and Liégeois, 2008; Gasquet et al., 2008), which collision age is set around $610 \mathrm{Ma}$. The collision supersedes the $\sim 680 \mathrm{Ma}$ arc-continent collision of the Sirwa arc (Gasquet et al., 2005; Gasquet et al., 2008) and precedes the Late Palæozoic Anti-Atlas collision.

\section{The East African and East Antarctica Collisions}

The East African orogen is often represented by a broadly deformed zone, separating Congo and Kalahari from India (e.g., Meert, 2003; Gray et al., 2007). However, it is believed herein that such a broad zone encompassed several sutures (Figures 3, 5). The Tanzanides runs from Kenya to Mozambique where it is prolonged by the Grunahogna suture (or Maud Belt) that continues into Antarctica (Fitzsimons, 2000; Fitzsimons, 2003; Harley et al., 2013). The collision ages reported along the Tanzanides spread from 650 to $680 \mathrm{Ma}$ (Gray et al., 2007; Key et al., 2011; Fritz et al., 2013). Those may be distinguished from ages along the Garissa suture in Somalia (Maboko and Nakamura, 2002; Collins et al., 2012), which is in the exact structural continuation of the Bongolava Ranotsara shear zone in the southern part of Madagascar (Raharimahefa and Kusky, 2006; Tucker et al., 2011; Fritz et al., 2013).

The Betsimisaraka suture, with age centered around $580 \mathrm{Ma}$ (Raharimahefa and Kusky, 2006) in the western and northwestern of Madagascar, may also be continued to the north with the Albroz suture up to Oman where a $560 \mathrm{Ma}$ age has been reported (Le Métour et al., 1995; see also Immenhauser et al., 2000; Saki, 2010). To the southeast of the Betsimisaraka suture, the structure is aligned with the Palghat-Cauvery suture in southern India (Tucker et al., 2011; Shan-Shan et al., 2017) and in Sri Lanka (Kröner and Brown, 2005). The suture can furthermore be continued in Antarctica where it is aligned with the LützowHolmbukta and central Dronning Maud Land (Fitzsimons, 2000; Fitzsimons, 2003; Leat et al., 2005) with age around $550 \mathrm{Ma}$ and later (550-450 Ma) reactivations. Following (Fitzsimons, 2003), the suture is not stopped in the middle of Antarctica, but is connected to the Shackleton Ranges in the Transantarctic Mountains.

\section{The Central Antarctica Collision}

(Fitzsimons, 2003) also suggested that a suture cross-cut the "heart" of the Antarctica continent. The author proposed three different hypotheses to separate the Mawson craton to the east and the craton of Antarctica to the west. Looking at the gravity anomalies (GGM02; Tapley et al., 2005), the area corresponding to the Mawson TE has a clear distinct signature from the Antarctica TE. This boundary, which well corresponds to the hypothesis \#3 of (Fitzsimons, 2003; see also "PD3" of Harley et al., 2013), has been used to draw the Gamburtsev suture (Figure 5), named so here after the Gamburtsev Subglacial Mountains (e.g., GSM of Harley et al., 2013; see also Aitken et al., 2014).

\section{The South American Collisions}

The main parts of South America (e.g., Santos et al., 2019; and Figure 3) are also separated by many sutures and fold belts with different names and ages, difficult to unambiguously connect with the rest of Gondwana. Much effort has therefore been made by many workers as early as Argand (1924) to characterize those connections. The Gurupi belt separating the São Luís craton from the Parnaíba Block, can be connected to the Dahomeyides and Adrar Fault in Western Africa (Klein and Moura, 2008), which peak age is around $620 \mathrm{Ma}$ (Blot et al., 1988; Affaton et al., 1991; dos Santos et al., 2008; de Araújo et al., 2010; Ganade de Araujo et al., 2014). The Borborema orogen, with ages around 600-620 Ma, separates the Borborema province from the São Francisco craton (Klein and Moura, 2008). It can be connected to the Yaoundé Belt and the Oubanguides to the East, and to the faults and shear zones in the Nigerian and Tuareg shields to the North, continued in the Aïr region by the Assodé - Issalane Serouenout area and the Tiririne Belt (Caby, 2003; Liégeois et al., 2003). The Araguaia belt (between the Amazon craton and the Parnaíba basin), prolonged to the south by the Paraguay belt (between the Amazon craton and the Paraná basin), borders the eastern edge of the Amazon craton. Although those areas have a long history (with the presence of the Goiás massif for instance; e.g., Pimentel et al., 2000), they can be connected to the Rokelides (Liberia, Sierra Leone). The collision age related to the final formation of Gondwana is assumed to be ca. 560-550 Ma (da Silva et al., 2005; dos Santos et al., 2008; Tohver et al., 2012). The Brasília belt separates the Paraná basin from the São Francisco craton. It has been well-studied (e.g., Pimentel et al., 2000; Laux et al., 2005; Valeriano et al., 2008; Rodrigues et al., 2010; Rodrigues et al., 2012; Trouw et al., 2013) and the age of collision between the Paranapanema TE and the São Francisco TE is taken at ca. $610 \mathrm{Ma}$ (see Oriolo et al., 2021 for a recent review). Further east, the model follows the interpretations of Stampfli et al. (2013) where two clusters of ages are considered: one around 600-580 Ma interpreted here as the collision of an active intra-oceanic magmatic arc turning the passive margin (dos Santos et al., 2008; Trouw et al., 2013) into an active margin; the second around $550 \mathrm{Ma}$ corresponding to the final collision between the Río de la Plata - Paranapanema TEs and the Congo (central Africa) TE. It is considered that the collision led to the 

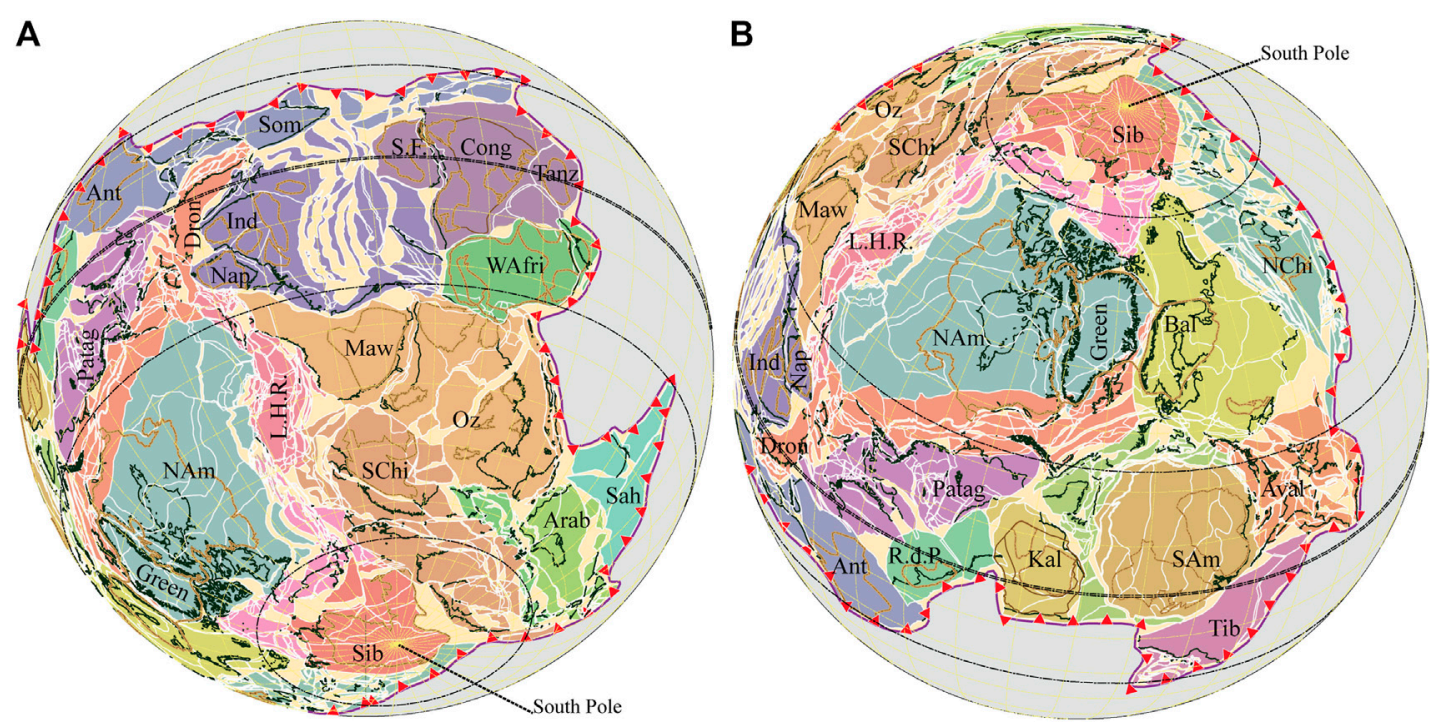

FIGURE 6 | Two different views of the Rodinia fit. Colors are random and merely highlight different domains discussed in the text (Ant: Antarctica; NAm; North America; SAm: South America; WAfri; West Africa; Cong: Congo/Central Africa; Arab: Arabia; Aval: Avalonia; Oz: Australia; Bal: Baltica; NChi: North China; SChi: South China; Dron: Dronning Maud; Green: Greenland; Ind: India; Kal: Kalahari; LHR: Lord Howe Rise; Maw: Mawson; Nap: Napier; Patag: Patagonia; RdP: Río de la Plata; SF: São Fancisco; Sah: Sahara; Sib: Siberia; Som: Somalia; Tanz: Tanzania; Tib: Tibesti). Every domain (see Figure 1) contain many TEs.

final formation of the Dom Feliciano, Ribeira, Araçuaí belts in South America, continued by the West Congo, Kaoko, and Gariep belts in Africa (e.g., Gray et al., 2008).

\section{The Ubendian and the Damara and Kuunga Collisions}

The Damara and Kuunga orogenies (Figure 3) are considered here (so as in Stampfli et al., 2013) as the youngest events regarding the formation of Gondwana with ages ranging from 550 to $490 \mathrm{Ma}$ (e.g., Boger et al., 2002; Hanson, 2003; Gray et al., 2006; Gray et al., 2008; see also Daczko et al., 2018). The presence of Neoproterozoic eclogite (Boniface and Appel, 2018) further north, within the Mesoproterozoic and Paleoproterozoic (Boniface et al., 2014; Thomas et al., 2019) Ubendian Belt near Lake Tanganyika, suggests the formation of sea-floor between the Bangweulu TE and the Tanzania TE. Boniface and Appel (2018) further suggested that the closure of the oceanic domain was followed by a collision at $c a$. $570 \mathrm{Ma}$. Therefore, this event must have occurred before the collision leading to the formation of the Damara Belt and its eastward continuation, the Lufilian Arc and Zambezi belt (Kampunzu and Cailteux, 1999; Gray et al., 2008).

\section{THE 888 MA FIT}

The initial configuration of Rodinia at $888 \mathrm{Ma}$ is based on a series of geological evidence (below) and the postulate that all continents were indeed assembled and no continental fragment were present in the Mirovoi Ocean (Powell and Pisarevsky, 2001) surrounding Rodinia. The postulate is obviously quite speculative as some TEs, in particular small ones, are left attached to others because of the lack of evidence of the contrary. Note that the term "continent" is used herein to name a series of associated TEs, without considering their relationship to sea-level (i.e., flooded or not), some of which are not attached to the present-day continents anymore. The configuration of Rodinia (Figure 6) has thus been constructed as follows:

\section{Amazonia - Baltica - Laurentia}

Johansson (2009) showed convincing evidence for the fit between Amazonia and Baltica. His SAMBA model (Johansson, 2014) is also connected to Laurentia in relation with the Grenvillian Orogeny in agreement to other authors (e.g., Dalziel, 1997; Li et al., 2008; Evans, 2009). Accounting for numerous smaller TEs, the same connection is used for the configuration in PANALESIS (Figure 6B).

\section{Laurentia - South China - Australia - Mawson}

The "Missing-Link" configuration proposed by Li et al. (1995); Li et al. (2008), largely on the basis of correlations between "intercontinental" dykes (Li et al., 2003; Li et al., 2008) in Laurentia, South China and Australia, is adopted here (Figure 6A). Note, however, that many TEs are added around the "core" of Laurentia. In particular, TEs belonging to the Ouachita and Pampia "terranes" are placed to the South and South-East of Laurentia (in present-day North American coordinates), in agreement, for instance, with Johansson (2014), and overall, in agreement with the Late Ediacaran - Early Palæozoic history of the area (see below). To the South-West of Laurentia, TEs belonging to the Lord Howe Rise (LHR in Figure 6) or Tasman "terranes" (or part 
of what is now also often named Zealandia; e.g., Adams, 2008; Grobys et al., 2008) are placed in the prolongation of South China, and linked to the Mawson TE, which is the southern extension of Southern Australia as heavily reported and commonly accepted in the literature (e.g., Vérard, 2004 and references therein).

\section{Mawson - Napier - India - Azania}

Following (Li et al., 2008) again, the "Napier continent", i.e., TEs including India - or "Greater" India - and Rayner in particular, are located next to the Mawson TE, along the future Gamburtsev suture. The latter is defined after evidence provided, in particular, by Fitzsimons (2003) and lineaments visible on geophysical imaging (topographic after ETOPO1, Amante and Eakins, 2009; magnetic after EMAG2, Maus et al., 2009; gravimetric after GRACE model, Tapley et al., 2005); (see The Central Antarctica Collision section). However, the suture must correspond to the amalgamation of the Antarctica and Mawson TEs (as is the configuration today), implying that the juxtaposition of "Napier continent" and the "Mawson continent" at $888 \mathrm{Ma}$ may have resulted from a previous tectonic collision (see, for instance, Boger, 2011; Aitken et al., 2014).

The location of the Azania terrane, including the Dronning Maud, Tanzania and Somalia TEs among others, within Rodinia is largely uncertain. Those elements are thus placed in the continuation of the Mawson TE (more or less present-day south of India) in a similar location as that as suggested by $\mathrm{Li}$ et al. (2008) and references therein.

\section{Laurentia - Siberia - North China}

As in the "original" SWEAT configuration of Rodinia proposed by (Hoffman, 1991) or the AUSMEX configuration used by (Pisarevsky et al., 2003); see also (Wingate et al., 2002), in particular, and references therein), Siberia and North China are here somewhat located to the north and east of presentday North America, a configuration that has also been used by $\mathrm{Li}$ et al. (2008) (see also the "consensus" reconstruction of Rodinia after Nance et al., 2014 and references therein).

\section{São Francisco - Congo - Tanzania - West Africa}

Despite minor motion related to the Cenozoic East African Rift, it is well-accepted (e.g., Hoffmann, 1991; Dalziel, 1997; Weil et al., 1998; Hoffmann, 1991; Karlstom et al., 2000; Meert and Powell, 2001 and related papers, and De Waele et al., 2008) that São Francisco-Congo-Tanzania TEs (S.F., Cong., Tanz. in Figure 6) were linked together since at least $888 \mathrm{Ma}$.

Palæomagnetic data as well as other geological information are very poor and quite inconclusive on the (pseudo-)absolute position of those elements in (or off) Rodinia. Most of the authors (cited above) place those elements at relatively high southern latitudes at $888 \mathrm{Ma}$, often in nearly similar tectonic relationship with the Kalahari area than it is today. However, De Waele et al. (2008) showed that a near-equatorial position is a viable palæomagnetic option, although they argue for an "independent craton" in this case. Tohver et al. (2006) also consider the "São Francisco - Congo craton" in nearequatorial position, which also corresponds to the retained APW path for PANALESIS.

Moreover, after many attempts, it seems that any motions of the Congo tectonic plate from a location in high southern latitudes is hampered by the other plates. The alternative nearequatorial option is thus retained in the $888 \mathrm{Ma}$ fit presented here.

Similarly, the location of West Africa is subject to caution. Although most authors (cited above) locate West Africa at high southern latitudes, none of these studies report associated palaeomagnetic poles in their data compilation (see for example the Table 1 of Li et al., 2008 or Table 1 of Merdith et al., 2017). Only Tohver et al. (2006) report data for West Africa (see their Table 1) but none between 998 and $775 \mathrm{Ma}$ (mean ages between their "W2" and "W3" data). The presence of collisional orogen and juvenile crust in West Africa (e.g., Bessoles, 1977; Naba, 2007; Tairou et al., 2012; Leprêtre, 2015; Block, 2015), however, mimicking those of Central South Africa (De Waele et al., 2009; Thomas et al., 2019), suggest a potential connection between the West Africa and Congo TEs, and is tentatively used to support its position in the $888 \mathrm{Ma}$ fit of Rodinia chosen here.

\section{Río De La Plata - Kalahari - Tibesti - Sahara}

Although many authors have studied the Río de la Plata, Kalahari and "Saharan meta-craton" areas - good example being the recent volume of Siegesmund et al. (2018) — very little is known about their location within Rodinia. Some authors (e.g., Oriolo et al., 2017) suggest that the Congo-São Francisco and Río de la Plata were separated from Rodinia, and point out that no palaeomagnetic poles exist for Río de la Plata from 1.5 to $0.6 \mathrm{Ga}$ (Cordani et al., 2003). Many other authors however [e.g., again Hoffmann, 1991; Dalziel, 1997; Weil et al., 1998; Hoffmann, 1991; Karlstrom et al., 2000; Meert and Powell, 2001; Li et al., 2008; Evans, 2009; Johansson, 2014; Merdith et al., 2017 (see their Figure 1) and references therein] place the Río de la Plata and Kalahari elements relatively close one another, and somewhat to the south and east of the present-day North America. Given the paucity of information, the $888 \mathrm{Ma}$ fit for PANALESIS merely follows this latter convention.

The location of "Saharan metacraton" (Abdelsalam et al., 2002; Liégeois et al., 2013) at $888 \mathrm{Ma}$ remains unknown. While it is missing in most representation of Rodinia (see all works but two among those just cited above), it is argued here that the Tibesti domain and Sahara domain must have been present at $888 \mathrm{Ma}$ but separated until the Ounianga collisional event occurred (The Saharan and Central African Collisions section and below). Some relics of passive margins are preserved along eastern Amazonia (Pimentel et al., 2000; Stewart, 2009) and along the Onib Sol Hamed suture (Abdelsalam et al., 2002; Abd ElRahman et al., 2012), and suggest that some elements must have detached to create oceanic basins and related passive margins. The Tibesti and Sahara domains, which otherwise cannot be seemingly fitted elsewhere, are good candidates for those elements. 


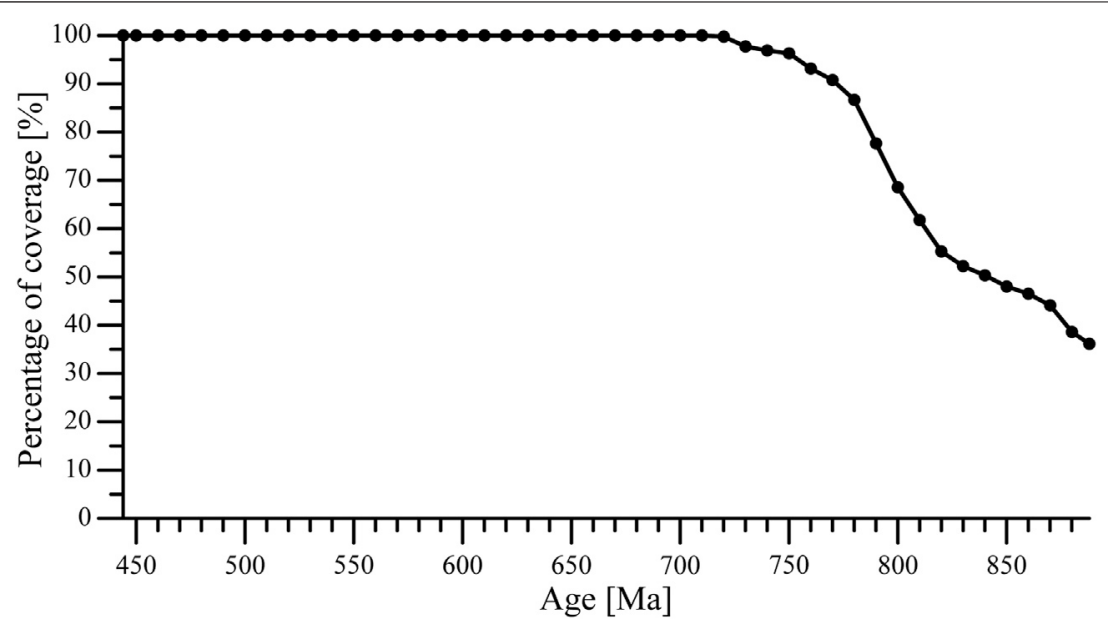

FIGURE 7 | Percentage of the Earth's surface covered by the reconstructions

\section{TECTONIC EVOLUTION}

The Rodinia fit (Figure 6) corresponds to the reconstruction of $36.1 \%$ of the Earth's surface (Figure 7). That coverage rises up above $95 \%$ at $750 \mathrm{Ma}$ and reaches $100 \%$ at $710 \mathrm{Ma}$, meaning that the degree of freedom for the reconstructions is relatively high at the beginning and decreases accordingly throughout the Tonian.

Many attempts have been made in order to move all tectonic plates-and associated TEs-on the globe over the 444 million years considered here. The model presented below correspond to the solution which complies to all geological data found on the one hand, and to the principles (geometric, kinematic, geodynamic) of Plate Tectonics on the other hand, from the fit defined at $888 \mathrm{Ma}$ for Rodinia (The $888 \mathrm{Ma}$ Fit section). The section therefore highlights how the main geological events from 888 to $444 \mathrm{Ma}$ are interpreted in the framework of the PANALESIS plate tectonic model (Figure 8; from 08.a to 08.p, with legend in Figure $\mathbf{8 Q}$ ). Note that the description of the tectonic evolution is conjugated to the present tense, although PANALESIS is a model and therefore, by definition, the retained options are open to criticism, in particular if geological data (e.g., age, type, relationship) and the starting Rodinia fit are confirmed or refuted in the future.

\section{8-860 Ma}

From 888 to $860 \mathrm{Ma}$ (Figure 8A), Rodinia breaks up starting with the separation of the Congo tectonic plate from the rest of Rodinia. Following Tack et al. (2001) who suggested break-up between $c a .910$ and $800 \mathrm{Ma}$ west of the Zadinian and Mayumbian Groups, a rift to drift zone is interpreted to develop between the present-day northern Greater India and the São Francisco-Congo-northern West Africa at ca. $870 \mathrm{Ma}$. A Tonga-Kermadec type of intraoceanic subduction zone also develops from the (present-day) western margin of West Africa. The migrating arc contains the Iskel island arc of Caby (2003) and Liégeois et al. (2003) (Figure 8B).

\section{0-830 Ma}

About $860 \mathrm{Ma}$ (Figure 8B), the mid-oceanic ridge separating the Congo and the Iskel plates enters subduction transferring extentional stresses to the upper plate. This event leads to the rift to drift zone between the Sahara plate (encompassing in particular the Borborema, Nigerian, Sahara and White Nile TEs) and the Rodinia plate. Meanwhile, the ridge ceases and jumps into the Iskel arc, which is in turn obducts onto the Latea TE on the Rodinia plate at ca. $850 \mathrm{Ma}$ (Caby, 2003; Liégeois et al., 2003).

At about the same age, the Gaoga plate (including in particular the Tuareg and Tibestian TEs), Kalahari plate, Crohn plate (with in particular the Antarctica and Tanzania TEs), and the Napier plate (with Greater India and the Dronning Maud and Somalia TEs among others) detach from Rodinia.

\section{0-800 Ma}

Around $830 \mathrm{Ma}$ (Figure 8C), the promontory of the Napier plate, which includes in particular the Air, Haya, Gebeit, Qambdo and Shan TEs collides with the Congo plate, leading to the tearing of West Africa relative to Congo. West Africa detaches with a strikeslip motion from Congo and starts its journey toward the North Pole.

\section{0-770 Ma}

Most tectonic plates keep on growing through sea-floor spreading (Figure 8D). One plate boundary of the Crohn plate has to be continued by an intraoceanic island arc, which collides with the passive margin of Napier and its promontory around $780 \mathrm{Ma}$. The collision is needed to turn the passive margin into an active margin. On the other side of the Napier plate, the motion leads to a ridge failure between the Napier plate and the "Australian side" of the Rodinia plate. The ridge failure changes the stress state and leads to the formation of a rifting zone around $770 \mathrm{Ma}$ between the Australia - Mawson area and the South China - Laurentian side of Rodinia (e.g., Li et al., 1995; Li and Powell, 2001; Bogdanova et al., 2009). The rifting is accompanied by the 

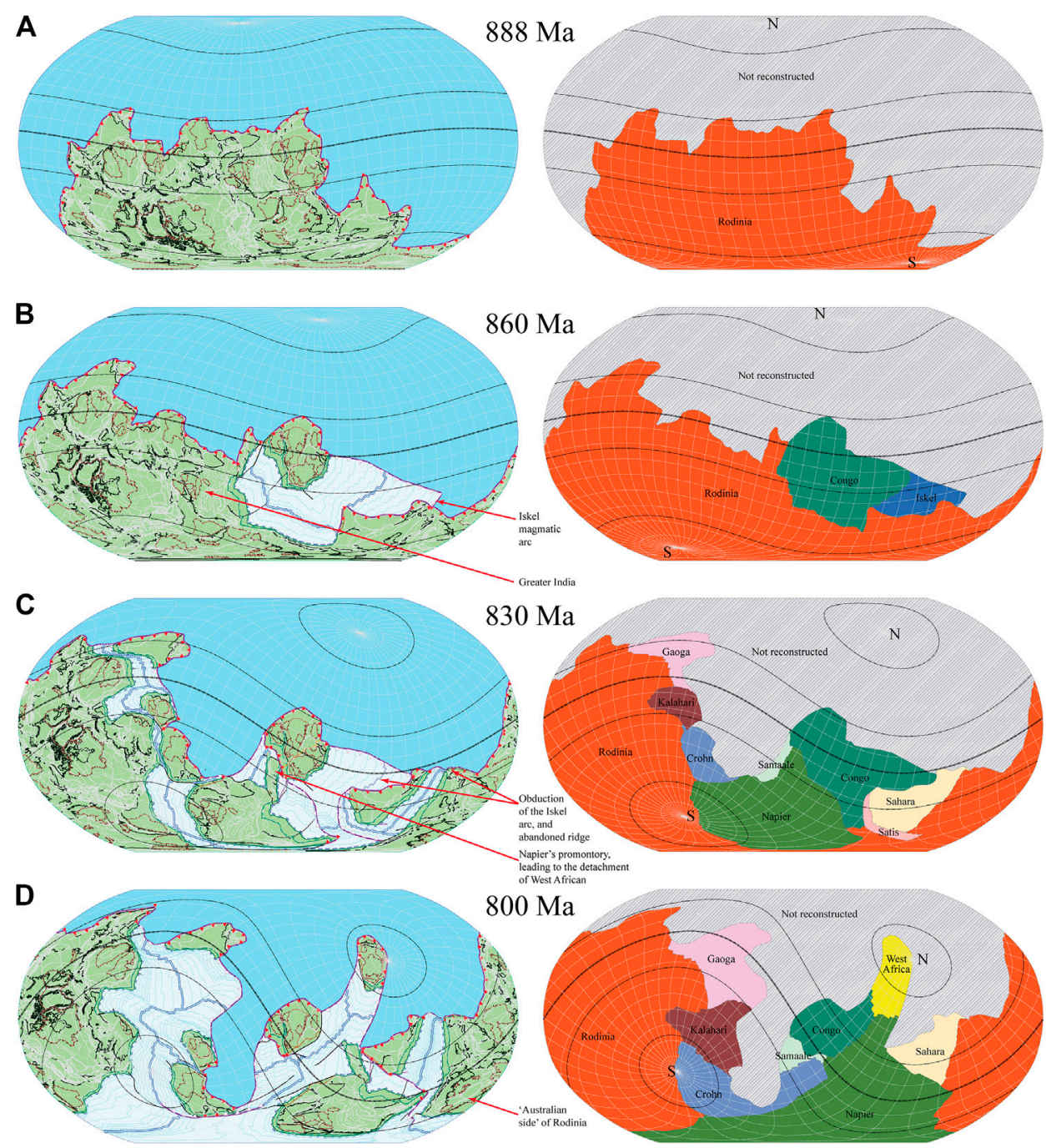

FIGURE 8 | (A)-(D) - The Panalesis plate tectonic model; left: reconstruction maps (see legend in Figure 8Q); right: tectonic plates (random colors). (E)-(H) - The Panalesis plate tectonic model; left: reconstruction maps (see legend in Figure $\mathbf{8 Q}$ ); right: tectonic plates (random colors). (I)-(L) - The Panalesis plate tectonic model; left: reconstruction maps (see legend in Figure $\mathbf{8 Q}$ ); right: tectonic plates (random colors). (M)-(P) - The Panalesis plate tectonic model; left: reconstruction maps (see legend in Figure $\mathbf{8 Q}$ ); right: tectonic plates (random colors). (Q)-Legend of the Panalesis plate tectonic model.

formation of the Kangding-Gunbarrel large igneous province (e.g., Ernst and Youbi, 2017 and references therein).

The Crohn plate collides with the Napier plate, predominantly between the Bekily - Madurai Block TEs and the Dronning Maud TE (see ages in Shan-Shan et al., 2017), along a zone which is nowadays marked by the Grunehogna suture.

Meanwhile, the Crohn plate also collides with the Kalahari plate, along the Namaqua - Rehoboth TEs and the Antarctica TE.

\section{0-740 Ma}

Between 760 and $750 \mathrm{Ma}$ (Figure 8E), following the collision between the Crohn and Napier tectonic plates, the Bekily, East and West Madagascar Ridge, Madurai Block, Sri Lanka, and Niassa TEs are left attached to the Napier plate, and separates from the Antarctica TE which belonging to the Crohn plate, and gives birth to the Mozambique Ocean (e.g., Santosh et al., 2009) at 750-740 Ma.

At ca. $750 \mathrm{Ma}$, the collision between the Kalahari and Crohn plates collapses, and the two plates subsequently separates again from one another.

Oceanisation (in the sense of the separation of two continental crusts) also occurs between the Mawson plate (which includes most of present-day Australia and the Mawson TE) and the rest of the Rodinia tectonic plate.

At $c a .750 \mathrm{Ma}$ in addition, to the present-day north of Greater India, the Napier plate separates from the Abyssinia plate (with in particular the Tokar-Barka, Bidah and ArAr TEs), and the Napier promontory split in two with the Qamdo and Shan TEs remaining on the Napier promontory and Aïr - Haya Gebeit TEs (among others) being detached with the Nubia plate. 

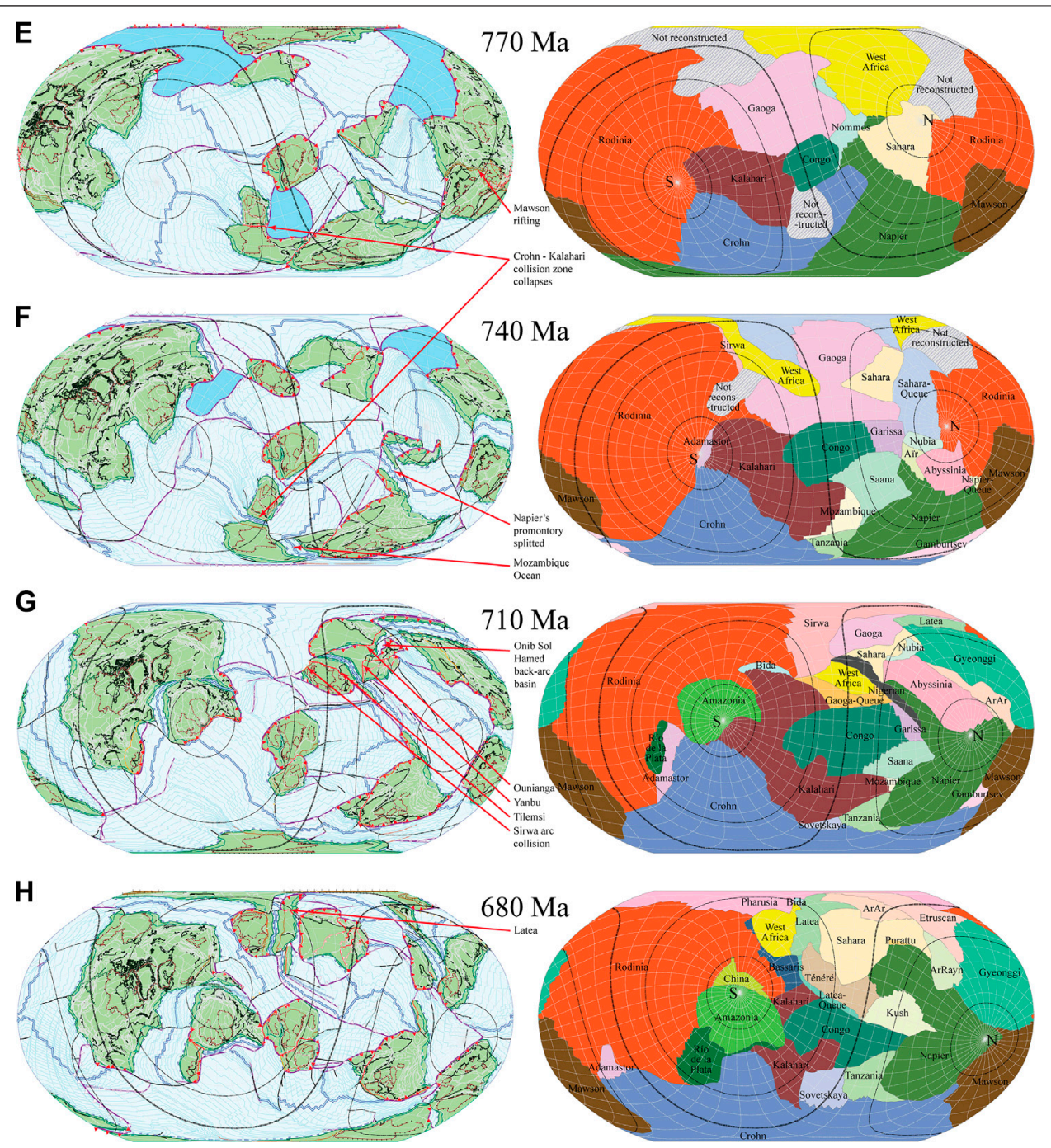

FIGURE 8 | (Continued).

Around $740 \mathrm{Ma}$, the Aïr TE detached the Nubia plate, which, in turn, becomes partly consumed by the Abyssinia plate.

A transpressional collision begins along the (future) Ounianga line between the Gaoga plate (including the Tibestian TE) and the Sahara plate (with the Sahara TE in particular), supported by a $c a$. 740 Ma granitoid in the Mayo Kebbi region (Penaye et al., 2006) and the "positive gravimetric anomaly" of (Louis, 1970) (The Saharan and Central African Collisions section) running through the Mayo Kebbi area.

The motion of the West Africa plate is associated with the formation of an intra-oceanic subduction zone, which collides with the active margin of Rodinia on its "North China - Tarim side." The collision leads to the detachment of an intra-oceanic island arc forming part of the Sirwa plate.

\section{0-710 Ma}

The Ounianga collision remains active (Figure 8F), hindering the motion of the Sahara plate. The subduction that takes place on the other side of the plate leads to its breakup and the opening of the Onib Sol Hamed back-arc basin. This opening, however, is stopped by the beginning of the collision around $720 \mathrm{Ma}$ between the Nubia plate (with in particular the Haya and Gebeit TEs) and the Sahara plate (including the White Nile, Bayuda, Gabgada, Allaqi-Heiani, and Midyan TEs among others). This Yanbu collision at $c a$. $710-700 \mathrm{Ma}$ (e.g., Johnson et al., 2011) triggers the inversion of one of the passive margin and the closure of the Onib Sol Hamed basin (Fitches et al., 1983). Likewise, the Abyssinia plate (with Tokar-Barka, Bidah, Jiddah, and ArAr TEs among others) collides with the Nubia plate (e.g., Haya, Gebeit, and Amman TEs) along the Ar-Ar suture (or Bi'r Tuluhah - Bi'r Umq Tharwah ophiolites; Johnson and Woldehaimanot, 2003; Stoeser and Frost, 2006).

While the motion of the latter plates is hindered by those collisions, slab roll-back leads to the detachment of the Nigerian - Borborema - Aïr TEs within the Nigerian 


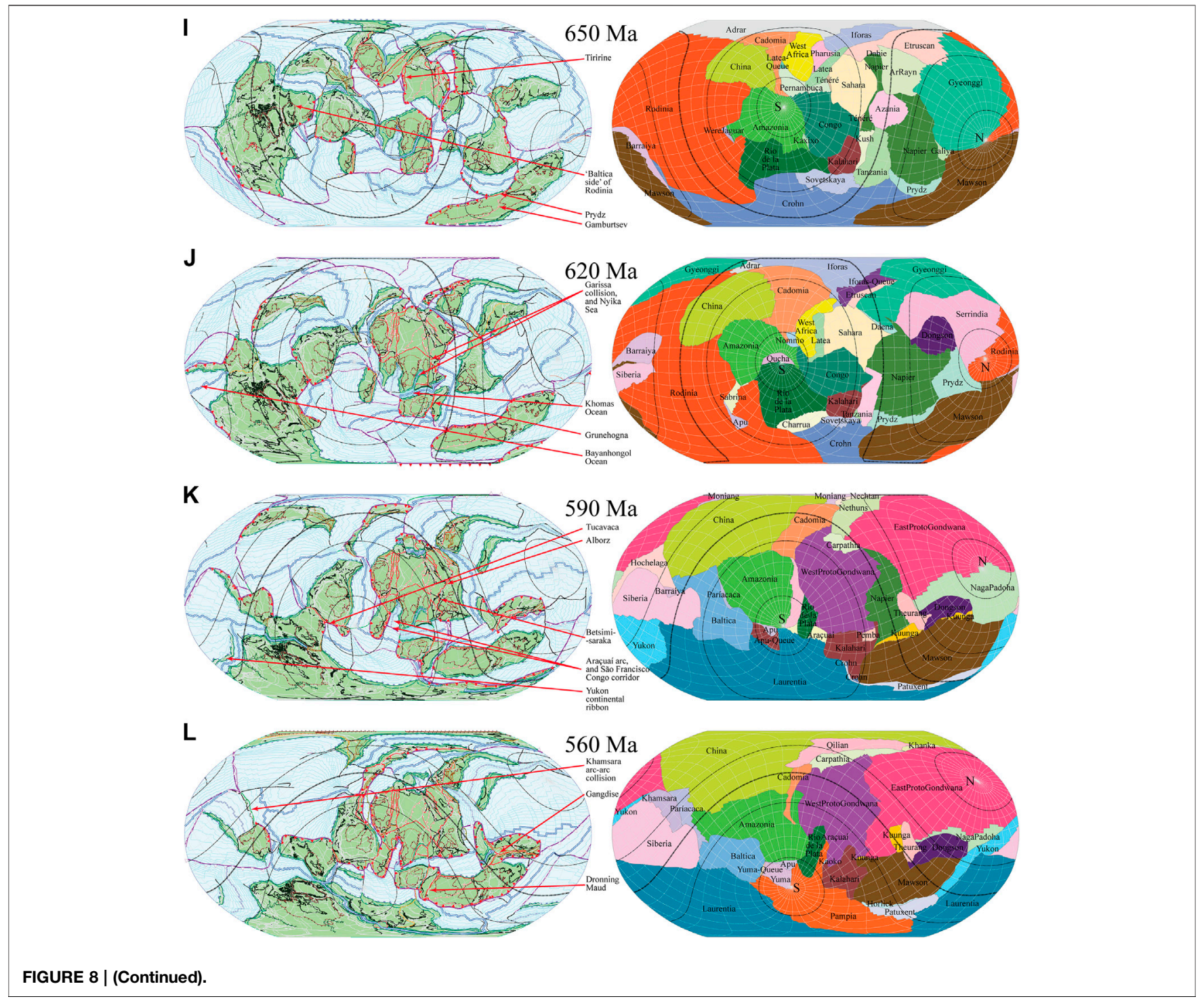

plate. The motion of that plate is however rapidly stopped by the Tilemsi collision (Caby, 2003; Liégeois et al., 2003) with the West Africa plate.

The Sirwa oceanic arc (or Siroua; Gasquet et al., 2008; Villeneuve et al., 2015) collides with the (present-day) northern edge of the West Africa craton at ca. 720 Ma. The subsequent inversion of the passive margin changes stresses and "pulls" West Africa and its newly amalgamated Nigerian Borborema - Aïr TEs away from the Sahara plate.

Around 730-720 Ma, the Gyeonggi plate (including TEs such as South China, Cathaysia, Indochina, Sibu and Ar Rayn) detaches from the Rodinia plate. As a consequence of this detachment, the Latea plate (with the Latea TE) also separates from Rodinia and the Gyeonggi plates.

The motion of the Kalahari plate leads to the formation of a transpressive transform fault between the Congo TE and the Zimbabwe and Lufilian TEs.
The intra-oceanic subduction zone that moves away from the Crohn, Kalahari and Congo plates toward the "Amazonian and Río de la Plata side" of Rodinia forms the Adamastor Ocean (de Brito-Neves et al., 1999; Rapela et al., 2007). Consecutively to the collision of that arc, the inversion of the passive margin of Rodinia into an active margin changes stresses in the upper plate and leads to the detachment of the Amazonia plate and then the Río de la Plata plate.

\section{0-680 Ma}

The Ounianga collision (between the Tibestian and Sahara TEs) and all Nubian and western Arabian collisions end (Figure 8G).

Strike-slip motion tears up the Ar Rayn plate (with the Ar Rayn and Sanandaj TEs among others) from the Etruscan plate (including in particular the Abruzzi, Adria, Pelagonia, SitiaPindos and Umbria-Marches TEs), which is equally a rifted portion of the Gyeonggi plate. 


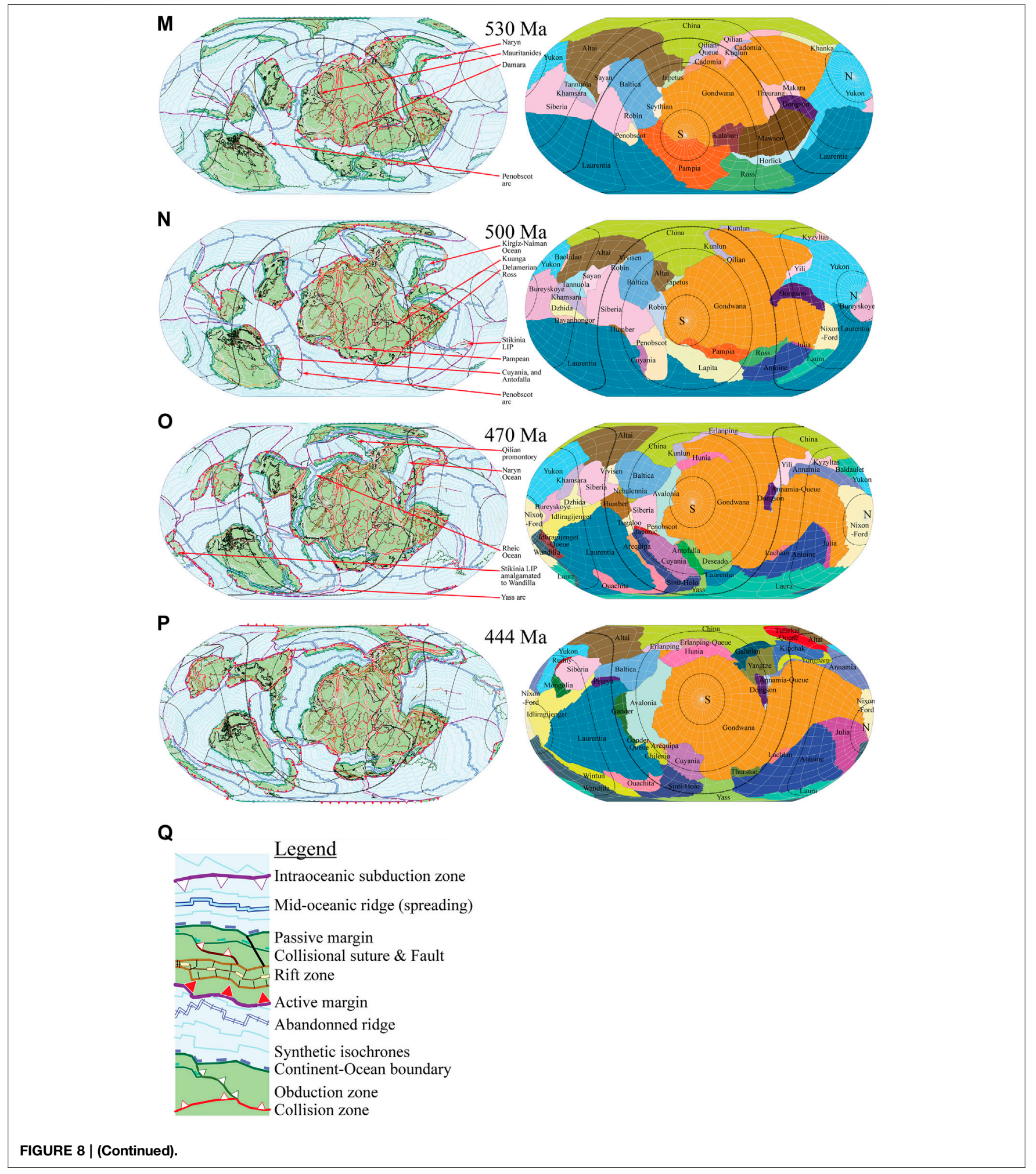

Around 700-690 Ma, the Pharusia plate forms, detaching the Iforas, Dahomeyides and also the Central Armorica, Mancellia, Pelagia and Pharusia TEs (among others) from Rodinia. At ca. $680 \mathrm{Ma}$, the Pharusia plate slides along a transpressive transform fault with the West Africa plate.
Subsequent new stress regime leads to the collapse of the Tilemsi orogen and the detachment of the Nigerian and Borborema TEs, which rapidly collides with the Latea plate and form the eclogites found by Liégeois et al. (2003), at the present-day south of the Laouni terrane in Algeria. 


\section{0-650 Ma}

The Crohn plate (with the Antarctica TE) and the Mawson plate (with Mawson TE) collides at about 680-670 Ma and form the Gamburtsev Orogeny (Figure $\mathbf{8 H}$ ), which corresponds to the suture suggested by (Fitzsimons, 2003; see The East African and East Antarctica Collisions section).

The Napier plate is subject to extension. A continental ribbon detaches to form the Prydz plate, which will collide diachronously along the passive margin of the Antarctica TE (Crohn plate) and invert it into an active margin from $c a$. $650 \mathrm{Ma}$ (e.g., Harley et al., 2013 and references therein). The collision that occurred at around $780-770 \mathrm{Ma}$ between the Crohn and Napier plates collapses, and a rift to drift process leads to the separation of the Tanzania plate (with in particular the Bekily, Madurai Block, Sri Lanka and Tanzania TEs). The Azania plate (including Antananarivo, Garissa, Somalia and Amlah TEs among others) follows a similar motion and then moves toward the Sahara plate.

A rift zone forms along the future Damara and Lufilian belts, continued into the Ubendian belts as evidenced by the presence of alkali magmatism (Mbozi syenite, $685 \pm 62 \mathrm{Ma}$ after Cahen and Snelling, 1966; Brock, 1968). The rifting phase is followed by the creation of a small ocean between the Tanzania TE and Bangweulu TE as evidenced by Boniface et al. (2012); Boniface et al. (2014) and Boniface and Appel (2018).

The Aïr TE collides with the Tuareg TE along the Tiririne Belt (Liégeois et al., 2003) at ca. $670 \mathrm{Ma}$.

The China plate (including the North China, SongliaoZhangguangcai, and Nuhetdavaa-Enshoo TEs among others) detaches at $c a$. $660 \mathrm{Ma}$ both from the "Baltica side" (i.e., Volgo-Uralia, Zemlya TEs) of Rodinia and from the Amazonia plate. Meanwhile, the Cadomia plate (which then includes the Aghdarband, Anarak, Badakshan, Bassarides, Betic, Bucovinian, Dacides, East Ossa-Morena, Eastern Tell, Hindu-Kush, Kabylies, Karakum, Mauritanides, Mid-German Crystalline High, North Pamir, Panormides, Rif Interne, Sidi, South Kunlun and Zongulak-Kure East TEs) equally moves away from the China plate. The evolution of the Cadomia plate (see below) is related herein to the formation of the different West African collisions (The West African Collisions section) but does not contradict studies on the provenance of detrital zircons (e.g., Žák and Sláma, 2018; Stephan et al., 2019) mainly carried out on Cambrian - Ordovician (i.e., younger) rocks.

\section{0-620 Ma}

From ca. $650 \mathrm{Ma}$ (Figure 8I), the Pharusia TE collides with the Nigerian and Latea TEs, and slides along the nowadays " $40^{\circ} 5$ " fault," whereas the Nigerian and Latea TEs slides along the Aïr TE along the Serouenout belt (Caby, 2003; Liégeois et al., 2003).

The Cadomia plate collides along the Souttoufides of Villeneuve et al. (2015) at 660-650 Ma, and along the Bassarides at 650-640 Ma (Villeneuve, 1984; Gasquet et al., 2005; Villeneuve, 2005; Villeneuve et al., 2006; Gasquet et al., 2008). Those collisions will nevertheless quickly collapse, and the Cadomia plate will again move away from West Africa from $c a$. $640 \mathrm{Ma}$.
Around $640 \mathrm{Ma}$, the Azania plate collides with the Sahara plate forming the Garissa suture, whereas the Tanzania plate collides with the Congo plate along the Tanzanides (e.g., Meert, 2003; Sommer et al., 2005). The latter collision stops the opening of the small ocean between the Bangweulu and Tanzania TEs, and opening jumps into the Zambezi belt area, i.e., between the Bangweulu and Lufilian TEs and the Kalahari plate (John et al., 2003; John et al., 2004).

The Garissa collision is accompanied by the Afif collision, which allows the amalgamation of the ArRayn plate with the Sahara plate along the Al Amar fault (or Abu Jir trend of Stern and Johnson, 2010) and also the Hulayfa-Ad Dafinah-Ruwah shear zones (Johnson and Woldehaimanot, 2003; Stoeser and Frost, 2006). This collision is believed to reactivate to a large extent most of the sutures in the west Arabian Peninsula and eastern Africa, and to be responsible for the dates obtained around those ages in the area (e.g., Meert, 2003). The amalgamation of the ArRayn plate is also interpreted as the cause of a ridge failure between the ArRayn plate and the Gyeonggi plate, leading to the splitting of the latter. Consequently, the Serindia plate (including in particular the Cathaysia, Eastern China Sea, Indochina and Spratley TEs) separates from the Gyeonggi plate (e.g., with the South China TE).

At about $640 \mathrm{Ma}$ also, the Dronning Maud plate (including in particular the Dronning Maud, East and West Madagascar Ridge, and Nagercoil Block TEs) separates from the Napier plate. On the "other side" of the Napier plate, the Baoshan, Gangdise and Qiantang TEs rift and drift away forming the Dongson plate.

From ca. 630 to $620 \mathrm{Ma}$, the Sahara plate collides with the Congo plate along the Oubanguides (e.g., Ouabego-Kourtene, 2013).

Large transpressional motion of the Iforas plate from $c a$. 650 to $620 \mathrm{Ma}$ leads to the formation of the double-sided UGI subductions of Caby (2003) between the Iforas TE and the Pharusia TE. This Pharusides orogeny is continued to the present-day south by the Dahomeyides orogeny between the Dahomeyides TE and the Nigerian TE. Near simultaneously, the Iforas and Dahomeyides TEs collides against the West Africa craton along the Western Suture (Caby, 2003; Liégeois et al., 2003). The two collision zones (Pharusides-Dahomeyides and Western Suture) merge and extend to the south-west into the Gurupi Belt between the São Luís TE and the Borborema TE. To the east, the Serouenout collision between the Latea and Air TEs, prolonged to the south between the Nigerian and Tuareg TEs, further extends as the Borborema belt between the Borborema and São Francisco TEs in present-day South-America (e.g., Ganade de Araujo et al., 2014).

To the present-day western margin of North-America, after the Barraiya plate went up and inverted the passive margin of Rodinia, the Bayanhongol ocean forms through the detachment of the Baiddrag-Bzabkhan, Central and West Gobi-Altai, East and West Lake, Hamar-Davaa, Idermeg, Ikat-Barguzin, MogochaTynda, North and South Baikal-Muya, Tannuola and TuvaMongolia TEs (Wilhem, 2010; Wilhem et al., 2012 and references therein). 


\section{0-590 Ma}

The rotation of the latter TEs (from the Baiddrag-Bzabkhan TE to the Tuva-Mongolia TE) forms a queue that becomes part of the Siberia plate (Figure 8J), which comes into existence at around $610 \mathrm{Ma}$. On the "Baltica side" of Rodinia (North Caspian, Sarmatia TEs), a "soft," largely transpressional collision with the Amazonia plate is associated to the formation of the Tucavaca belt (or Tucavaca Aulacogen; e.g., Ramos, 2010). Despite that "soft" collision, the Baltica plate detaches from Laurentia, in a rotational motion accompanying the movement of Siberia.

The Yucatan TE is believed to rift and drift from the Pampia and Yuma TEs (within the Rodinia plate), forming the Apu plate at ca. $610 \mathrm{Ma}$. The motion of the Yucatan TE (Apu plate) ends with the Pinar del Río collision with the Río Apa TE (Amazonia plate) at ca. $590 \mathrm{Ma}$ (Rapela et al., 2007; Rapela et al., 2011; Santos et al., 2019).

At the same time, the Río de la Plata plate (and its Paranapanema TE) starts colliding with the Congo plate (and its São Francisco TE) to form the Brasília orogeny (Pimentel et al., 2000; Rodrigues et al., 2010; Pimentel et al., 2011).

At ca.620 Ma, the Dronning Maud plate collides with the Kalahari plate along the Mozambique suture ( 625 and $605 \mathrm{Ma}$ ages in the Usambara granulites; Maboko and Nakamura, 2002) which, according to the model, must extend to the Grunehogna suture (or Maud Belt; see also Figures 3, 5). The collision stops the sea-floor spreading in the Khomas ocean (future Damara Belt) between the Kalahari and Congo plates.

The Napier plate converges toward the Congo plate and collides from 600 to $580 \mathrm{Ma}$ along the Alborz collision, which runs along the Sanandaj, Alborz, Semail, Ruwah and Somalia TEs, to the Betsimisaraka suture in Madagascar and the PalghatCauvery suture in India (see The East African and East Antarctica Collisions section), and forms the WestprotoGondwana continent.

The motion of the Dongson plate away from the Napier plate leads to a collision with the Serindia plate at ca.630-620 Ma. This Qiantang collision results in the cessation of sea-floor spreading in the Naryn Ocean between the Serindia plate and the Gyeonggi plate, the inversion of the passive margin of the Dongson plate into an active margin, and the opening of an ocean - the KirgizNaiman Ocean (Wilhem et al., 2012 and references therein) - between the Cathaysia, Chu-Yili, Eastern China Sea, IssykKul and Yili-Erementau TEs (then belonging to the Gyeonggi plate) and the Dongson plate (with the Indochina and Spratley TEs in particular). In addition to those events, the mid-oceanic ridge between the Napier plate and the Prydz plate enters into subduction under the Mawson plate at ca. $610 \mathrm{Ma}$. In relation to the change in stress regime of the upper plate, the Kuunga plate forms and detaches the Andaman-Argo, North and South WoylaArgo, Seram and Timor TEs (among others). Following the passage of the Dongson plate, the Theurang plate (including in particular the High Himalaya, Himalayan Tethys and Lhasa TEs) separates from the Napier plate and soon collides with both the Dongson plate and Kuunga plate, which equally collides along the Gangdise suture.
At ca. 610-600 Ma, the transform fault accompanying the motion of Siberia is subject to compression and turns into an intra-oceanic subduction zone. Stresses are thus transferred to the passive margin of Rodinia, and a continental ribbon (including for instance the Bygrave, Kayrunnera, Central Quesnellia, Central and South Yukon-Tanana, Sierra-Nevada, Yukon-Tanana Nebesna, and Yukon-Tanana Teslin among others) breaks off, forming thereby the Yukon plate. In the axis of the sea-floor spreading, a rift zone creates and determines the Patuxent plate (which includes in particular the Horlick Mountains, Bowers, North-West Tasmania and Stavely TEs).

\section{0-560 Ma}

The latter TEs (i.e., Horlick Mountains, etc.) migrate toward the Mawson and Australian continents (Figure 8K), where they collide during the Ross Orogeny (e.g., Vérard and Stampfi, 2013a; Vérard and Stampfi, 2013b and references therein). The passive margin inversion related to the collision of that continental ribbon is associated with new stress regimes and the formation of the Pampia plate (which includes among others, the Pampia, Patagonia, Deseado TEs, the Ellsworth-Whitemore, Marie Byrd Land, Amundsen, South Challenger Plateau TEs, and the Wagga-Omeo, Wentworth and Parkes-Tumut TEs).

At ca. $580 \mathrm{Ma}$, the Antarctica TE collides with the Dronning Maud TE creating the Dronning Maud Orogeny. The collision transfers stresses to the Kalahari plate, and the mid-oceanic ridge between the Kalahari and the West-protoGondwana plates fails. An intra-oceanic subduction initiates in this Khomas ocean, and will end up as an obduction front onto the Lufilian TE.

The Napier plate collides with the West-protoGondwana plate along the Alborz collision front that runs from Oman, along Somalia, and forms, mainly around $580 \mathrm{Ma}$, the Betsimisaraka suture in Madagascar and the Palghat-Cauvery suture in India. This Alborz collision, together with the collision of the intraoceanic arc of the Khomas ocean, leads to the closure, around 570-560 Ma (Boniface and Appel, 2018), of the Nyika Sea, named so after the Neoproterozoic eclogites found within the Paleoproterozoic (Boniface et al., 2014; Thomas et al., 2019) Ubendian belt.

The Araçuaí plate formed an intra-oceanic subduction zone, the island arc of which penetrated the corridor between the São Francisco and Congo TEs and collided their passive margins. That collision is considered to be responsible for the inversion of the passive margins into active margins.

At ca. $580 \mathrm{Ma}$, the Qilian plate (with, among others, the Qilian, Qaidam, Eastern Pontides, Sakarya, North and South Getic, Moldanubian TEs) detaches from the China plate. It collides with the Cadomia and Carpathia plates at around $560 \mathrm{Ma}$, and inverts the "southern" passive margin of that continental ribbon. This will lead to the closure of the basin to the "north" of Gondwana, and bring all the TEs of the Qilian and Cadomia plates back toward Gondwana.

\section{0-530 Ma}

Around $550 \mathrm{Ma}$ (Figure 8L), the collision of the continental part of the Cadomia plate and Amazonia plate leads to the formation of the Mauritanides (i.e., the "Pan-African II tectonic event" of 
Villeneuve, 2005), the Rokelides, and the Paraguai Belt. Those collisions, in addition to the previous inversion of the passive margins along the Río de la Plata, Paranapanema and Congo TEs, result in the closure of the ocean basin and the collision corresponding to the Dom Feliciano, Brasília, Ribeira, West Congo, Kaokao, and Gariep belts (e.g., Gray et al., 2008). The Yuma TE is also amalgamated to the Amazonia plate.

From (present-day) west to east, the Damara Orogeny (i.e., Damara belt, Lufilian belt, Zambezi belt; Gray et al., 2008) will form from $\mathrm{ca}$. 540 to $490 \mathrm{Ma}$.

The Dongson plate collides with the Mawson plate along the present-day north-western margin of Australia. The collision, together with the Ross Orogeny in Antarctica and Australia, generates intra-plate stresses related to the formation of the Alice Spring Orogeny and the Musgrave Belt.

The subduction of the mid-oceanic ridge under the Horlick Mountain TE on the one hand, and the amalgamation of the Yuma TE with associated passive margin inversion on the other hand, leads to extentional stress regime within the Pampia plate, which split in two. From 550 to $540 \mathrm{Ma}$ therefore, the Ross plate rifts and drifts from the Pampia plate. The Ross Orogeny, however, collapses in Antarctica, leading to the formation of the Horlick plate, while the Diamantina rift system forms in Australia.

In relation with the rotation of the Baltica plate, the Scythian plate rifts and drifts at ca. 550-540 Ma from the Amazonia plate, and a collision with the Baltica continent will rapidly occur $c a$. 530-520 Ma (Şengör and Natal'in, 2007; Wilhem, 2010).

Following Wilhem (2010) also, the arc-arc collision occurring at ca. $560 \mathrm{Ma}$ between the Khamsara arc (including in particular the Central and West Gobi-Altai, East Mandalovoo, Tannuola and Khamsara TEs) and the intra-oceanic island arc at the boundary of the China plate, changes the stress regime, and transfers extension on the continental area of the China plate. Consequently, a rift to drift phase occurs which leads to the formation of the Altai plate (which includes, among others, the Songliao-Zhangguangcai, Gurvansayhan-Zoolen, Inner Pechora, Baolidao, North and Central Rudny-Altai, Chinese-Altai, Central Mandalovoo TEs).

The Cadomia and Carpathia plates collides the "northern" margin of Gondwana around 540-530 Ma along the High-Altas TE, the Mancellia, Apulia, Talea Ori TEs, and Massif Central, Aquitania TEs among others (e.g., von Raumer and Stampfli, 2008).

\section{0-500 Ma}

Following the collision previously mentioned between the Cadomia and Carpathia plates (Figure $\mathbf{8 M}$ ), the orogen collapses and is accompanied by widespread extension in Gondwana, marked by the formation of many rifts, for instance in the Amazonia basin, in the High Atlas, in the Murzuq and Al Kufrah area, and the Taurus area (e.g., von Raumer et al., 2015). The Qilian TE, in particular, detaches from Gondwana at ca. $520 \mathrm{Ma}$, and is left behind as the intra-oceanic island arc drift off from it at $c a .510 \mathrm{Ma}$ and forms the Qaidam Ocean (von Raumer et al., 2012; Stampfli et al., 2013; von Raumer et al.,2015).
The heart of Gondwana is being complete as the Damara orogeny prolonged by the Kuunga orogeny and Pinjarrra orogeny end. The Theurang plate also collides with Gondwana mainly between 520 and $510 \mathrm{Ma}$ along a suture between the High Himalaya TE and the East and West Lesser Himalaya TEs (Baig et al., 1988; Sharma, 1998; Stampfli et al., 2013; Myrow et al., 2016; Roy and Purohit., 2018). Subsequently, the Dongson plate (now including the East and West Aktau-Junggar, Indochina, Macclesfield, Spratley and West Sumatra TEs) rift and drift again from 520-500 Ma from the "Australian side" of Gondwana.

On the "other side" of Australia, the Horlick plate collides with the Ross plate at 520-510 Ma forming the Ross Orogeny, and also inverting the passive margin of the former Horlick plate into an active margin. The oceanic basin behind the Horlick continental ribbon therefore closes, and the Ross plate eventually collides with Gondwana around $505 \mathrm{Ma}$ to form the Delamerian Orogeny (e.g., Vérard and Stampfli 2013a).

Meanwhile, the Pampia plate also collides with Gondwana along a suture running from the Transantarctic Mountains in Antarctica, to the Saldanha Belt in South Africa, and the Pampean Belt in South America (e.g., Rapela et al., 2007).

Along Laurentia, the passage of the Penobscot intra-oceanic subduction inverts the passive into an active margin (Stampfli et al., 2013). The Cuyania plate forms (Ramos, 2004), and the Cuyania and Antofalla TEs rift and drift away from 510 to $500 \mathrm{Ma}$. Likewise, the Humber plate (including the Tugaloo and Saint Laurent TEs) forms a bit later on, once the midoceanic ridge separating the Penobscot plate from the Siberia plate moves southwards (relative to the present-day position of Greenland).

\section{0-470 Ma}

The Cuyania plate mainly consumes the Penobscot plate and eventually subducts parts of the Penobscot intra-oceanic island arc itself (Figure $\mathbf{8 N}$ ). Subsequently, the Antofalla TE separates from the Cuyania TE at around $490 \mathrm{Ma}$, and the intra-oceanic island arc to the present-day south of Cuyania, equally split in two, leading to the formation of the Yass plate.

Extensional stress regime becomes also present in the Laurentia plate, leading to the formation between 490 and $470 \mathrm{Ma}$ of the Ouachita plate (including in particular the Black Rock, Tahue, Chortis, Coahuiltecano, Guchichil TEs, and then the North, Central and South Lord Howe Rise, Wanganella-Reinga, Norfolk Ridge, and North Challenger Plateau TEs; see also Vérard and Stampfli, 2013a).

After the amalgamation of the Ross and Pampia plates into Gondwana (560-530 Ma section), the inversion of the passive margins into active margins consumes the oceanic lithosphere of the Lapita and Antoine plates. At ca. $480 \mathrm{Ma}$, the Lapita plate - and its spreading axis - is entirely consumed, so that the Laurentia plate now subducts under Gondwana. The subduction of the mid-oceanic ridge leads to a change in stress regime in upper plate (Gondwana plate), which results in the creation of the Deseado plate (including among others the Famatina-Puna, Patagonia, Deseado, Larsen, Thurston Island, and Haag TEs). The Famatina-Puna TE, however, soon collides with the 
Antofalla TE (Ramos, 2004), and the collision leads to ridge failure at ca. $470 \mathrm{Ma}$ in the back-arc basin between FamatinaPuna and Gondwana.

In an equivalent extensional stress regime but located to the (present-day) east of Australia, the back-arc basin of the future Lachlan Fold Belt forms (e.g., Vérard and Stampfli, 2013a) in a time interval approximately centered around $470 \mathrm{Ma}$ as well.

Accompanying the aforementioned extensional events, a rift to drift event leads to the creation of the Avalonia plate (containing in particular the Carolina, North, West and Southwest Avalonia, Channel, Meseta, Mid-German Crystalline High TEs) and the Hunia plate (with the Karakum, Badakshan, HinduKush, North Pamir, South Kunlun and Qaidam TEs), and the formation of the Rheic Ocean (Stampfli et al., 2013).

The Altai plate, meanwhile, collides with the Khamsara plate along the Mandalovoo suture at around $490 \mathrm{Ma}$. Also, the Khamsara plate simultaneously collides with the Siberia plate (Wilhem, 2010). The Charysh-Terekta Ocean in front of the Khamsara subduction zone is thus free to be consumed, and the Khamsara arc is bended at $180^{\circ}$ as proposed by (Wilhem, 2010, and references therein; see also Domeier, 2018 for a revisited version from 500 to $420 \mathrm{Ma}$ ).

The Kunlun and Kunlun-Queue plates, which were created from the Qilian promontory (Qilian TE) of Gondwana, formed an intra-oceanic island arc that collides with the continent of the China plate. The arc-continent collision leads to the inversion of the passive margin of the China plate into an active margin, and the formation of extensional stress regime in the upper (China) plate (Stampfli et al., 2013). This extension results in the detachment of a continental ribbon being part of the Erlanping plate (including the Erlanping and North Qilian TEs).

The collision of the island arc of the Yukon plate at $c a .510 \mathrm{Ma}$ against the passive margin of the "Naryn" continental area (encompassing in particular the Cathaysia, Chu-Yili, Eastern China Sea, Issyk-Kul TEs; Gondwana plate), resulted in its inversion into an active margin. In addition, the motion of the Dongson plate leads, at $c a .500-490 \mathrm{Ma}$, to the Yili collision, mainly between the Indochina TE (Dongson plate) and Cathaysia TE (Gondwana plate). Because the Maikain-Kyzyltas Ocean belonging to the Yukon plate is free be consumed by the newly created active margin, the Yili plate (with the Chu-Yili, East and West Tar-Murontsev, Issyk-Kul, North-East and SouthEast Boshchekul-Chingiz, West Junggar-Yamaquan, and YiliErementau TEs) forms at ca. $500 \mathrm{Ma}$. Those elements (Yili plate), however, soon collide with the Dongson plate, and provokes a ridge failure, which generates an obduction front that consumes the Gondwana part of the Kirgiz-Naiman Ocean. The obduction front reaches the remaining TEs of the "Naryn" continental area of the Gondwana plate. Thenceforth, the second part of the Kirgiz-Naiman Ocean (Yili plate) closes as well, and all TEs from the Yili plate collides back approximately to the position where they were. The collision, however, results in the inversion of the other passive margin of the "Naryn" continental area, so that the Naryn Ocean starts to close (Wilhem, 2010).

When the Horlick plate formed (560-530 Ma section), the continental ribbon was accompanied by an intra-oceanic island arc derived from the present-day eastern side of Australia. After the Ross collision, that island arc was part of the Nixon-Ford plate, which was cross-cut by a major transform fault. It is assumed that the curvature of the Nixon-Ford island arc is related to differential rotation within the plate. The transform fault representing a weak zone, the Nixon-Ford plate splits into two parts at $c a .500 \mathrm{Ma}$ : the remaining Nixon-Ford plate and Laura plate. On the other side of the spreading axis, the oceanic area of the former Ross plate is now the Antoine plate (530-500 Ma section). Similarly, the aforementioned transform fault, which bounds the Antoine plate, is subject to compression due to plate rotation, so that the fault fails and an intra-oceanic subduction zone forms and gives birth to the Julia plate. It is also assumed that the initial differential rotation within the NixonFord plate, which eventually gave birth to the Laura, Antoine and Julia plates, is related to the arrival at the surface of a large igneous province (LIP). It is considered that this "Stikinia" LIP forms the basement of many TEs of present-day North America, namely: the Cadwallader, East, Central and West McKinkey, North, Central and South Nixon-Ford, North, East, Central and South Stikinia, Chatino, Chiliwack, Chulitna, East and West Koyukuk, East and West Pingstone, East and West Saint Laurent Ridge, East and West Wrangellia-Tlikakila, Klamath, Michumina, Moresby, Mystic, South Dillinger, Tracy Arm, Wallowa, Wrangellia-Kluane, and Wrangellia-Sicker TEs.

\section{0-444 Ma}

Around $470 \mathrm{Ma}$ (Figure 80), the island arcs of the Nixon-Ford and Laura plates collides both with the "Yukon" continental ribbon left behind on the Laurentia plate and with the island arc belonging to the Idliragijenget-Queue plate. The "Stikinia" LIP is also amalgamated to those arcs, and is subsequently part of the new Wandilla plate. Because all arc collisions have turned the passive margins of the "Yukon" continental ribbon into active margins, the Wandilla plate is subject to stretching, and split in two at ca. $460 \mathrm{Ma}$. The "Stikinia" LIP remains on the Wandilla plate, but most of the TEs belonging to the former the "Yukon" continental ribbon rift and drift off to form the Wintun plate.

It must noticed that the "Stikinia" LIP formed predominantly on the mid-oceanic ridges separating the Nixon-Ford, Laura, Antoine and Julia plates. Segment of that LIP that were left on the Antoine plate is considered to be responsible for the Benambran Orogeny (or Benambran phase of the Lachlan Orogeny) in Australia (Vérard and Stampfli, 2013a).

The migration of the Yass intra-oceanic arc results in a collision with the Deseado plate at ca. $460 \mathrm{Ma}$. The Antarctica Peninsula TE, in particular, is transferred from the (lower) Yass plate to the (upper) Deseado plate. The collision, however, stops the back-arc opening between the Deseado plate and Gondwana plate. With the spreading axis cessation, therefore, the Deseado plate ceases to exist and becomes part of the Gondwana plate. Note that it is considered that this back-arc basin will only close when the Patagonia TE (among the others) will collide with Gondwana along the "Northern Magmatic Arc" at around $300 \mathrm{Ma}$ (Ramos, 2008).

In the extension of the Yass arc, the Antofalla TE has collided with the Famatina-Puna TE. The Cuyania TE, that Ramos (2004) 
described as an isolated terrane from at least 490 to $460 \mathrm{Ma}$, was left behind, and eventually collides at around $460 \mathrm{Ma}$ (Ramos, 2004) with the newly created active margin along the Gondwana continent (i.e., Antofalla, Famatina-Puna and Pampia TEs).

Around $480-470 \mathrm{Ma}$, the migration of the Yass intraoceanic arc along the passive margin of Laurentia also turns that margin into an active margin, and leads to the rift and drift of the Ouachita plate (530-500 Ma section). The motion of the Ouachita plate, however, is eventually stopped at ca. $444 \mathrm{Ma}$ by the arrival of oceanic plateaus at the surface (forming the basement of the Bird's Head and East Coral Sea Block TEs) on the one hand, and the collision of parts of the Wintun plate (in particular North-East Klamath and Sierra Nevada TEs) against the Ouachita plate (in particular the Bellona Plateau, Cato Plateau, and North Lord Howe Rise TEs) on the other hand.

In the continuation of the Ouachita continental ribbon detachment, the Antofagasta, Arequipa and East Chilenia TEs equally detach from the present-day eastern margin of North America. The creation of these Chilenia and Arequipa plates is accompanied by the creation of the Tugaloo and Humber plates, which extends the intra-oceanic island arc from plate to plate. Note that the Antofagasta, Arequipa and East Chilenia TEs will only be amalgamated to Gondwana at around $400 \mathrm{Ma}$.

The collision of the Avalonia plate with the Baltica plate gives birth to a transpressional collision as soon as 480-470 Ma (e.g., Stampfli et al., 2013), in particular between the MidGerman Crystalline High and South-East Avalonia TEs (Avalonia plate) and the Karpinsky, Pre-Caucasus, Great Caucasus, Mangyshlak and Urs Yurt TEs (Baltica plate). The Avalonia plate, however, keeps on moving as transpressional transform fault along the margin of Baltica. Note that the "final" Caledonian Orogeny between Avalonia, Baltica and Laurentia, in particular along the Tornquisk Zone (see also, for instance, Erlström et al., 1997) occurs around 420-400 Ma (e.g., Torvik and Rehnström, 2003; Stampfli et al., 2013). This "early" transpressional collision, however, hinders the motion of the Avalonia plate, and generates extensional tension in the arc. The latter therefore split and gives birth to the Gander plate (Stampfli et al., 2013; and see the Ganderia terrane in; van Staal et al., 2012). The Gander arc (Gander plate) collides with the Tugaloo arc (Tugaloo plate) at $c a$. $450 \mathrm{Ma}$, inverting the passive margin of the Tugaloo plate, and bringing all associated TEs back toward Laurentia. The collision with Laurentia (mainly along the Appalachian Front TE) is shown at $444 \mathrm{Ma}$ (Figure 8P). Meanwhile, the Humber arc (Humber plate) collides with the Baltica continent at $c a .450 \mathrm{Ma}$, turning the passive margin of the Baltica plate into an active margin. In association with the subduction of the mid-oceanic ridge, the Baltica plate is subject to extension and leads to the formation of the Peary plate (which includes in particular the Svalbard, Pearya, Ostrov, LomonOstrov and Lincoln Sea TEs).

On the present-day northern side of Siberia, the Altai, Khamsara and Siberia plates are fully amalgamated by $460 \mathrm{Ma}$. The region, however, is soon subject to extension again, and a rifting phase occurs at $444 \mathrm{Ma}$, that will soon lead to the formation of the Rudny and Mongolia plates (Wilhem, 2010).

The Erlanping plate (530-500 Ma section) collides with the Qilian promontory at $c a .460 \mathrm{Ma}$, and further collides with the Hunia plate at 450-444 Ma (von Raumer et al., 2012; Stampfli et al., 2013; von Raumer et al., 2015).

To the east of present-day Africa, the Naryn Ocean is being consumed. The Dongson plate (in particular the Indochina and West Sumatra TEs) collides with the Gondwana plate (e.g., Central and South Pamir, Amman, South Aghil TEs) and Yangtze plate (e.g., Central and South Pamir, Amman, South Aghil TEs), while the Yili plate (e.g., Cathaysia and Eastern China Sea TEs) and Kipchak plate (e.g., East Chu-Saryu, East Teniz, East Tar-Murontsev, Selety-Erementau and Dulate-Baytag TEs) collides with the Yangtze plate (e.g., South China, Cheju Do, Naryn, West Chu-Sarysu, West Teniz TEs) at ca. $450 \mathrm{Ma}$. Following the collision, the Annamia continental ribbon (Annamia plate) detaches, and leaves a passive margin along the now (i.e., $444 \mathrm{Ma}$ ) amalgamated Yangtze and Kipchak plates (Wilhem, 2010; Wilhem et al., 2012).

\section{DERIVATIVE DATA}

Because the PANALESIS plate tectonic model reconstructs $100 \%$ of the Earth's surface (but see Figure 7), it means that not only continental areas but also oceanic realms are reconstructed. It implies it is possible to compute many derivative maps and data (e.g., Vérard et al., 2015a; Vérard et al., 2015b; Vérard, 2019a; Vérard, 2019b). For example, it is possible to compute the age of the sea-floor at every time slice at any point of the entire planet. One example of such map is shown here for the reconstruction at $444 \mathrm{Ma}$ (Figure 9A).

Given the sea-floor age distribution (Figure 9B) for this map, the mean age (and associated two-sigma uncertainty, $\mu \pm 2 \sigma$ ) of 466.6 $\pm 41.7 \mathrm{Ma}$ has probably little meaning (skewness $\gamma_{\mathrm{s}}=2.497$; kurtosis $\gamma_{\mathrm{k}}=10.056$; normal distribution shown in blue for comparison). Although more statistical analysis should be done to properly characterize this Poisson-like distribution, it seems to be more appropriate to consider, to first order, the median value (and associated absolute median deviation, $m \pm$ $\left.\varepsilon_{a m}\right)$ of $460.9 \pm 10.5 \mathrm{Ma}$. Such kind of consideration is true for all reconstructions, so that the absolute values given for the mean ocean age over time (Vérard et al., 2015a; Vérard et al., 2015b) must be considered with caution, although the general trend is certainly more robust.

For sake of alleviating a little bit the present-paper, only mean accretion rates calculated at every time slice at spreading axes and mean subduction rates calculated at trenches will be presented here (Figures 10, 11).

Accretion rates are defined from the total surface, in squarekilometers over the sphere, newly created at every time slice, and divided by the time interval between two maps (i.e., $10 \mathrm{Ma}$ ). Likewise, subduction rates correspond to the total surface (on the sphere surface) that is consumed per year. The two curves, provided in the time range from 888 to 


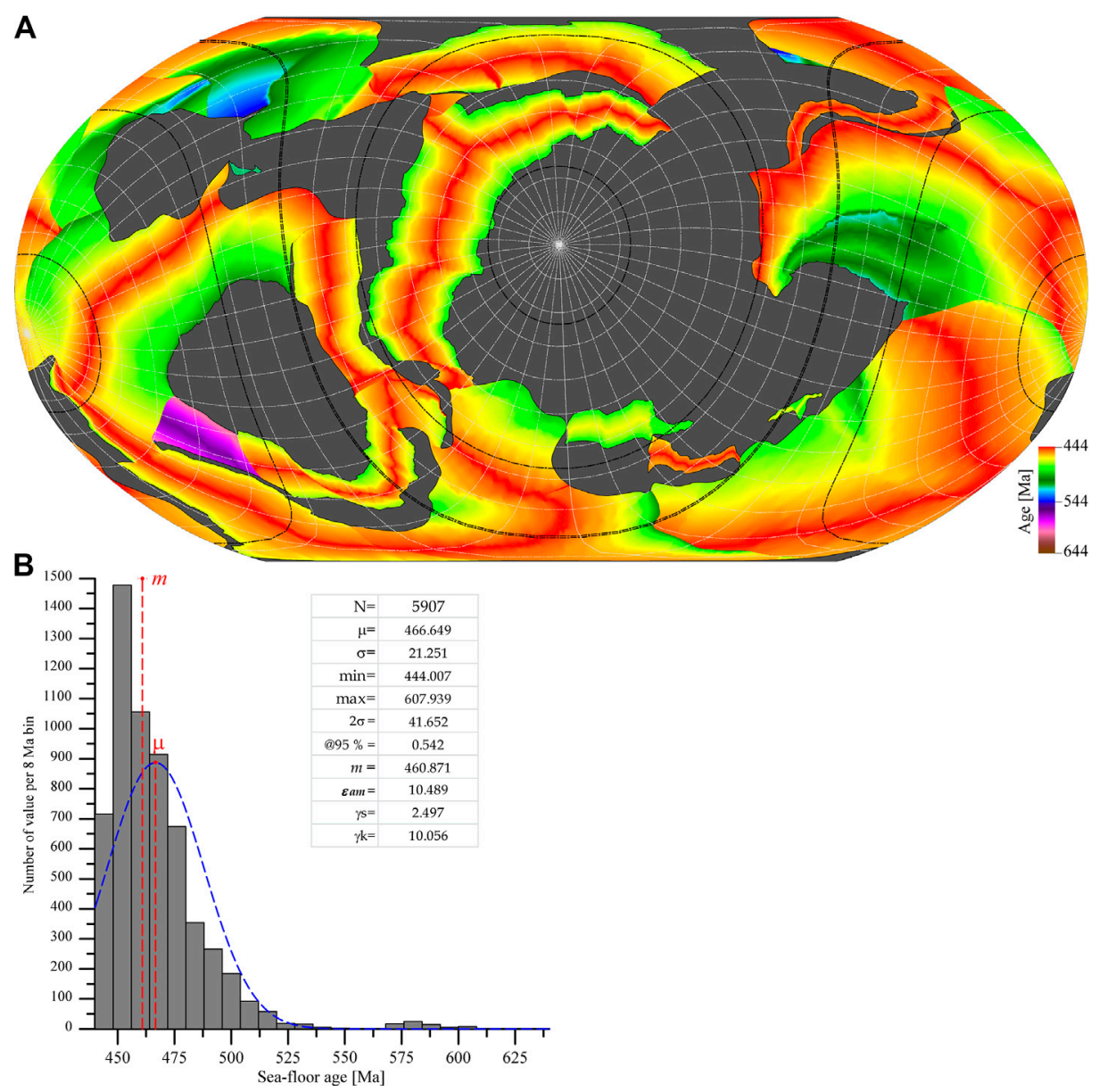

FIGURE 9 | Sea-floor age for the reconstruction at $444 \mathrm{Ma}$ (A) Color-coded global map (continental area in gray); (B) Age distribution and statistics (see text).

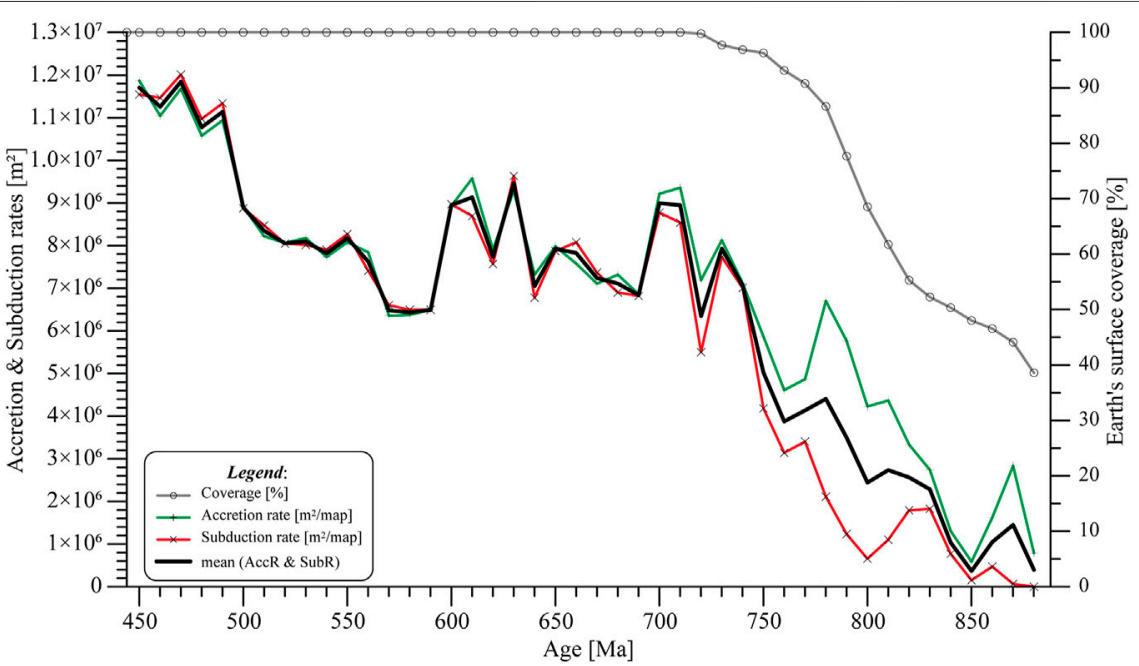

FIGURE 10 | Accretion rates at mid-oceanic ridges (red) and subduction rates at trenches (green) derived from the PANALESIS plate tectonic model; black: average value between accretion and subduction rates. The percentage of Earth's surface (gray) covered by the model is shown for reference (as per Figure 7). 


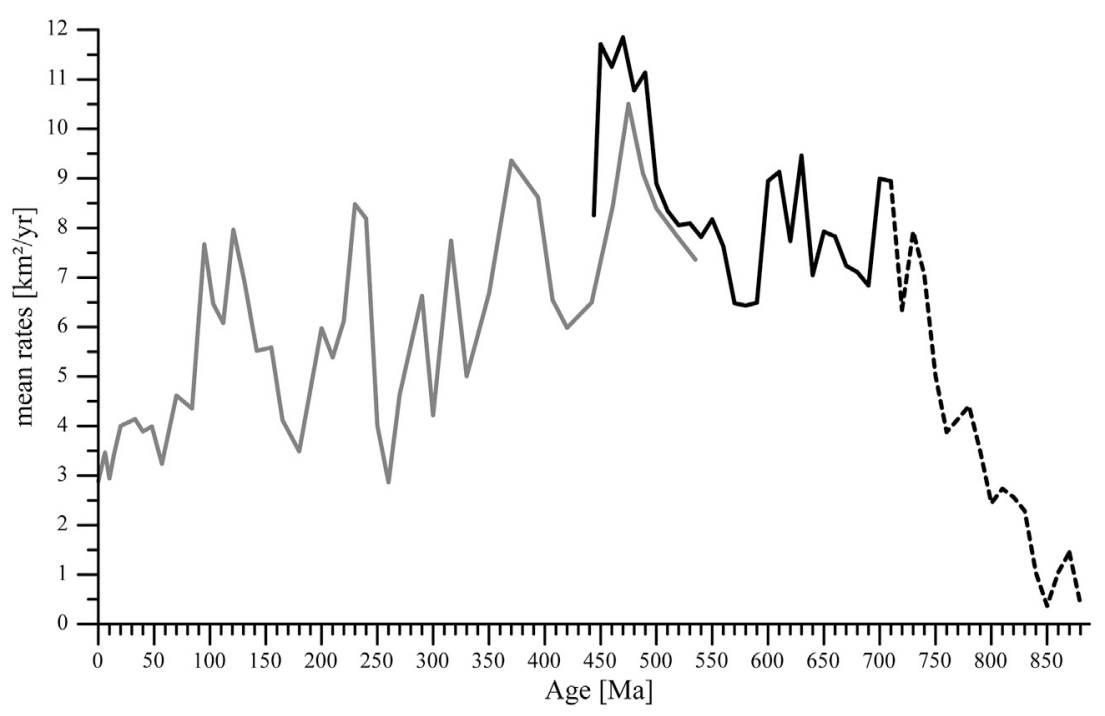

FIGURE 11 | Tectonic Activity (TA) index (in $\mathrm{km}^{2} / \mathrm{yr}$ ); black: derived from the PANALESIS model (this study), dashed line representing the part of the curve where coverage is inferior to 100\%; gray: derived from the UNIL model (Vérard et al., 2015a; Vérard et al., 2015b).

$444 \mathrm{Ma}$ (red and green curves in Figure 10), show a similar pattern, but values are not identical since surfaces may be accommodated by other processes of lithospheric stretching or shortening. Moreover, relatively large discrepancies can be observed from 880 to $\mathrm{ca}$. $750 \mathrm{Ma}$, because the model does not entirely (i.e., <100\%) reconstruct the Earth's configuration at those time slices, and therefore, tectonic plate surfaces are not correctly balanced.

To first order, however, one can observe a general increase in accretion and subduction rates from 888 to $444 \mathrm{Ma}$. To second order, the model suggests two relative maxima at around $700 \mathrm{Ma}$ and at 630-600 Ma, and a relative minimum at about $580 \mathrm{Ma}$, and to some extent, another minimum between 680 and $650 \mathrm{Ma}$. Without drawing any hasty conclusions, it may be worth noting that those two first minima correspond approximately to the timing of the Gaskiers and Marinoan glaciations. The clear decrease at $444 \mathrm{Ma}$, finally, is in good agreement with late Ordovician Hirnantian glaciation (e.g., Ghienne et al., 2014).

(Vérard et al., 2015a) have proposed a "combined tectonic rate" - or "tectonic activity" (TA) index (Vérard and Veizer, 2019) - derived from the UNIL plate tectonic model throughout the Phanerozoic. It is indeed considered that the mean global tectonic activity of the planet is primarily reflected by the mean value, in $\mathrm{km}^{2} / \mathrm{yr}$, between the accretion rates and subduction rates.

It is reassuring to note that the curves (black: PANALESIS versus gray: UNIL; Figure 11) are relatively similar over the period in which they overlap, even though the values from the PANALESIS model are slightly higher. It implies that the increase in TA index from 888 to $444 \mathrm{Ma}$ (Figure 10) is most likely apparent. Ignoring values from 888 to $c a .750 \mathrm{Ma}$ (dashed black curve in Figure 11) for which plate tectonic coverage in significantly inferior to $100 \%$, therefore, the general trend of the plate tectonic activity of our planet is decreasing, in agreement with general cooling of the Earth (Vérard et al., 2015a; Vérard et al., 2015b; see also; Vérard and Veizer, 2019).

\section{CONCLUSION}

The present paper proposes a solution for the reconstruction of the global plate tectonic history of the Earth from 888 to $444 \mathrm{Ma}$. The PANALESIS model, eventually reconstructing $100 \%$ of the Earth's surface (i.e., not only continental areas, but also oceanic realms), is regarded as geologically, geometrically, kinematically, and geodynamically coherent.

The model shows that the formation of Gondwana is the result of a complex history, where the Eastern and Western Pan-African Orogenies, in particular, cannot be merely represented as vague, broad zones of deformation, but must be considered as a succession of juxtaposed or overlapping tectonic events. The model posits tectonic scenarios for each of the 66 orogenic sutures shown for Gondwana in Figure 3. In addition, although it can be considered that Gondwana is finally amalgamated at 540-520 Ma with the Damara-Kuunga collision, the model suggests that amalgamation of "terranes" (or TEs) of different sizes is a roughly continuous process over time, and detachment or amalgamation of "peri-Gondwana terranes" continues to reshape Gondwana after the Early Cambrian.

Finally, this type of global modeling is important not only to retrieve the global geodynamic history of the Earth, but also to provide with many kinds of derivative maps and data, which can be compared to even larger sets of data in geosciences. This work 
will be completed as soon as possible by the release of the global plate tectonic history of the Earth from $444 \mathrm{Ma}$ to present-day.

\section{DATA AVAILABILITY STATEMENT}

The original contributions presented in the study are included in the article/Supplementary Material, further inquiries can be directed to the corresponding author.

\section{AUTHOR CONTRIBUTIONS}

$\mathrm{CV}$ created the model, wrote the manuscript, and generated the figures and data.

\section{REFERENCES}

Abdelsalam, M. G., Gao, S. S., and Liégeois, J.-P. (2011). Upper Mantle Structure of the Saharan Metacraton. J. Afr. Earth Sci. 60, 328-336. doi:10.1016/j.jafrearsci. 2011.03.009

Abdelsalam, M. G., Liégeois, J.-P., and Stern, R. J. (2002). The Saharan Metacraton. J. Afr. Earth Sci. 34, 119-136. doi:10.1016/s0899-5362(02)00013-1

Abd El-Rahman, Y., Polat, A., Dilek, Y., Kusky, T. M., El-Sharkawi, M., and Said, A. (2012). Cryogenian ophiolite tectonics and metallogeny of the Central Eastern Desert of Egypt. Int. Geol. Rev. 54 (16), 1870-1884.

Adams, C. J. (2008). Geochronology of Paleozoic Terranes at the Pacific Ocean Margin of Zealandia. Gondwana Res. 13, 250-258. doi:10.1016/j.gr.2007.07.001

Affaton, P., Rahaman, M. A., Trompette, R., and Sougy, J. (1991). "The Dahomeyide Orogen: Tectonothermal Evolution and Relationships with the Volta Basin," in The West African Orogens And Circum-Atlantic Correlatives. IGCP-Project 233 (Terranes in the Circum-Altantic Paleozoic Orogens). Editors R. D. Dallmeyer and J.-P. Lécorché (Berlin, Heidelberg: Springler), 107-122. doi:10.1007/978-3-642-84153-8_6

Aitken, A. R. A., Young, D. A., Ferraccioli, F., Betts, P. G., Greenbaum, J. S., Richter, T. G., et al. (2014). The Subglacial Geology of Wilkes Land, East Antarctica. Geophys. Res. Lett. 41, 2390-2400. doi:10.1002/2014gl059405

Amante, C., and Eakins, B. (2009). ETopo1 - 1 Arc-Minute Global Relief Model: Procedures, Data Sources and analysisNOAA Technical Memorandum Nesdis Ngdc-24. Boulder, Co, USA: National Geophysical Data Center, Marine Geology and Geophysics Division, 25.

Argand, E. (1924). La tectonique de l'Asie. Extrait du Compte-Rendu $d u$ XIII ${ }^{e}$ Congrès Géologique Int. 1922, Liège 1 (5), 171-372.

Baig, M. S., Lawrence, R. D., and Snee, L. W. (1988). Evidence for Late Precambrian to Early Cambrian Orogeny in Northwest Himalaya, Pakistan. Geol. Mag. 125 (1), 83-86. doi:10.1017/s0016756800009390

Bessoles, B. (1977). Mémoires du BRGM, 88. Paris, France: Bureau de Recherches Géologiques et Minières), 402.Géologie de l'Afrique : le craton ouest africain

Block, S. (2015). Evolution géodynamique de craton Ouest Africain au nord du Ghana. PhD thesis. France: University of Toulouse, Université Toulouse 3 Paul Sabatier, 419. Available at: https://dumas.ccsd.cnrs.fr/OMP-TEL/tel-01170855.

Blot, A., Affaton, P., Seddoh, K. F., Aregba, A. P., Godonou, S. K., Lenoir, F., et al. (1988). Phosphates du Protérozoïque supérieur dans la chaîne des Dahomeyides (circa $600 \mathrm{Ma}$ ) de la région de Bassar (Nord-Togo, Afrique de l'Ouest. J. Afr. Earth Sci. (and Middle East) 7 (1), 159-166. doi:10.1016/08995362(88)90062-0

Bogdanova, S. V., Pisarevsky, S. A., and Li, Z. X. (2009). Assembly and Breakup of Rodinia (Some Results of IGCP Project 440). Stratigr. Geol. Correl. 17 (3), 259-274. doi:10.1134/s0869593809030022

Boger, S. D. (2011). Antarctica - before and after Gondwana. Gondwana Res. 19, 335-371. doi:10.1016/j.gr.2010.09.003

Boger, S. D., Carson, C. J., Fanning, C. M., Hergt, J. M., Wilson, C. J. L., and Woodhead, J. D. (2002). Pan-African Intraplate Deformation in the Northern

\section{ACKNOWLEDGMENTS}

I thank the Sinergia PaleoC4 group, funded by the Fond National Suisse (FNS), for encouraging $m e$ in the development of the PANALESIS model in parallel to work done sensu stricto in the framework of the Sinergia project. I also thank SO and another reviewer for their kind comments and fruitful remarks.

\section{SUPPLEMENTARY MATERIAL}

The Supplementary Material for this article can be found online at: https://www.frontiersin.org/articles/10.3389/feart.2021.666153/ full\#supplementary-material

Prince Charles Mountains, East Antarctica. Earth Planet. Sci. Lett. 195, 195-210. doi:10.1016/s0012-821x(01)00587-8

Boniface, N., and Appel, P. (2018). Neoproterozoic Reworking of the Ubendian Belt Crust: Implication for an Orogenic Cycle between the Tanzania Craton and Bangweulu Block during the Assembly of Gondwana. Precambrian Res. 305, 358-385. doi:10.1016/j.precamres.2017.12.011

Boniface, N., Schenk, V., and Appel, P. (2014). Mesoproterozoic High-Grade Metamorphism in Pelitic Rocks of the Northwestern Ubendian Belt: Implication for the Extension of the Kibaran Intra-continental Basins to Tanzania. Precambrian Res. 249, 215-228. doi:10.1016/j.precamres.2014. 05.010

Boniface, N., Schenk, V., and Appel, P. (2012). Paleoproterozoic Eclogites of MORB-type Chemistry and Three Proterozoic Orogenic Cycles in the Ubendian Belt (Tanzania): Evidence from Monazite and Zircon Geochronology, and Geochemistry. Precambrian Res. 192-195, 16-33. doi:10.1016/j.precamres.2011.10.007

Brock, P. W. G. (1968). Metasomatic and Intrusive Nepheline-Bearing Rocks from the Mbozi Syenite-Gabbro Complex, Southwestern Tanzania. Can. J. Earth Sci. 5 (3), 387-419. doi:10.1139/e68-039

Caby, R., and Kienast, J. R. (2009). Neoproterozoic and Hercynian Metamorphic Events in the Central Mauritanides: Implications for the Geodynamic Evolution of West Africa. J. Afr. Earth Sci. 53, 122-136. doi:10.1016/j.jafrearsci.2008. 09.004

Caby, R. (2003). Terrane Assembly and Geodynamic Evolution of central-western Hoggar: a Synthesis. J. Afr. Earth Sci. 37, 133-159. doi:10.1016/j.jafrearsci.2003. 05.003

Cahen, K., and Snelling, N. J. (1966). The Geochronology of Equatorial Africa. Amsterdam, Netherlands: North-Holland Publishing Co. Ltd.

Collins, A. S., Kinny, P. D., and Razakamanana, T. (2012). Depositional Age, Provenance and Metamorphic Age of Metasedimentary Rocks from Southern Madagascar. Gondwana Res. 21, 353-361. doi:10.1016/j.gr.2010.12.006

Condie, K. C. (1992). Proterozoic Crustal Evolution. Developments in Precambrian Geology, 10. Elsevier Science Publishers B. V., 537.

Condie, K. C. (2003). "Supercontinents, Superplumes and continental Growth: the Neoproterozoic Record,”. Proterozoic East Gondwana : Supercontinent Assembly and Breakup. Editors M. Yoshida, B. F. Windley, and S. Dasgupta (London: Geological Society, Special Publications), 206, 1-21. doi:10.1144/gsl. sp.2003.206.01.02 Geol. Soc. Lond. Spec. Publications

Cordani, U. G., D’Agrella-Filho, M. S., Brito-Neves, B. B., and Trindade, R. I. F. (2003). Tearing up Rodinia: The Neoproterozoic Palaeogeography of South American Cratonic Fragments. Terra Nova 15, 350-359. doi:10.1046/j.13653121.2003.00506.x

Cox, G. M., Lewis, C. J., Collins, A. S., Halverson, G. P., Jourdan, F., Foden, J., et al. (2012). Ediacaran Terrane Accretion within the ArabianNubian Shield. Gondwana Res. 21, 341-352. doi:10.1016/j.gr.2011. 02.011

da Silva, L. C., McNaughton, N. J., Armstrong, R., Hartmann, L. A., and Fletcher, I. R. (2005). The Neoproterozoic Mantiqueira Province and its African 
Connections: a Zircon-Based U-Pb Geochronologic Subdivision for the Brasiliano/Pan-African Systems of Orogens. Precambrian Res. 136, 203-240. doi:10.1016/j.precamres.2004.10.004

Daczko, N. R., Halpin, J. A., Fitzsimons, I. C. W., and Whittaker, J. M. (2018). A Cryptic Gondwana-Forming Orogen Located in Antarctica. Sci. Rep. 8 (8371), 9. doi:10.1038/s41598-018-26530-1

Dalziel, I. W. D. (1997). OVERVIEW: Neoproterozoic-Paleozoic Geography and Tectonics: Review, Hypothesis, Environmental Speculation. Geol. Soc. America Bull. 109 (1), 16-42. doi:10.1130/0016-7606(1997)109<0016:onpgat >2.3.co;2

de Araújo, C. E. G., Pinéo, T. R. G., Caby, R., Costa, F. G., Cavalcante, J. C., Vasconcelos, A. M., et al. (2010). Provenance of the Novo Oriente Group, Southwestern Ceará Central Domain, Borborema Province (NE-Brazil): A Dismembered Segment of a Magma-Poor Passive Margin or a Restricted Rift-Related basin? Gondwana Res. 18, 497-513. doi:10.1016/j.gr.2010.02.001

De Waele, B., Fitzsimons, I. C. W., Wingate, M. T. D., Tembo, F., Mapani, B., and Belousova, E. A. (2009). The geochronological framework of the Irumide Belt: A prolonged crustal history along the margin of the Banweulu Craton. Am. J. Sci. 309, 132-187.

De Waele, B., Johnson, S. P., and Pisarevsky, S. A. (2008). Palaeoproterozoic to Neoproterozoic growth and evolution of the eastern Congo Craton: Its role in the Rodinia puzzle. Precambrian Res. 160, 127-141.

Dewey, J. F., and Burke, K. C. A. (1973). Tibetan, Variscan, and Precambrian Basement Reactivation: Products of Continental Collision. J. Geology 81 (6), 683-692. doi:10.1086/627920

Domeier, M. (2018). Early Paleozoic Tectonics of Asia: Towards a Full-Plate Model. Geosci. Front. 9, 789-862. doi:10.1016/j.gsf.2017.11.012

Domeier, M., and Torsvik, T. H. (2014). Plate tectonics in the late Paleozoic. Geosci. Front. 5, 303-350.

dos Santos, T. J. S., Fetter, A. H., and Neto, J. A. N. (2008). "Comparisons between the Northwestern Borborema Province, NE Brazil, and the Southwestern Pharusian Dahomey Belt, SW Central Africa,". West Gondwana Precenozoic Correlations across the South Atlantic Region. Editors R. Pankhurst, R. Trouw, B. de Brito Neves, and M. de Wit (London: Geological Society, Special Publications), 294, 101-120. doi:10.1144/sp294.6 Geol. Soc. Lond. Spec. Publications

Ennih, N., and Liégeois, J.-P. (2008). "The Boundaries of the West African Craton, with Special Reference to the Basement of the Moroccan Metacratonic Antiatlas belt,". The Boundaries of the West African Craton. Editors N. Ennih and J.-P. Liégeois (London: Geological Society, Special Publications), 297, 1-17. doi:10.1144/sp297.1 Geol. Soc. Lond. Spec. Publications

Erlström, M., Thomas, S. A., Deeks, N., and Sivhed, U. (1997). Structure and Tectonic Evolution of the Tornquist Zone and Adjacent Sedimentary Basins in Scania and the Southern Baltic Sea Area. Tectonophysics 271, 191-215. doi:10. 1016/s0040-1951(96)00247-8

Ernst, R. E., and Youbi, N. (2017). How Large Igneous Provinces Affect Global Climate, Sometimes Cause Mass Extinctions, and Represent Natural Markers in the Geological Record. Palaeogeogr. Palaeoclimatol. Palaeoecol. 478, 30-52. doi:10.1016/j.palaeo.2017.03.014

Evans, D. A. D., Li, Z. X., and Murphy, J. B. (2016). Four-dimensional Context of Earth's Supercontinents. London: Geological Society, Special Publications, Vol. 424, 1-14. doi:10.1144/sp424.12

Evans, D. A. D. (2009). "The Palaeomagnetically Viable, Long-Lived and AllInclusive Rodinia Supercontinent Reconstruction,". Ancient Orogens and Modern Analogues. Editors J. B. Murphy, J. D. Keppie, and A. J. Hynes (London: Geological Society, Special Publications), 327, 371-404. doi:10. 1144/sp327.16 Geol. Soc. Lond. Spec. Publications

Fitches, W. R., Graham, R. H., Hussein, I. M., Ries, A. C., Shackleton, R. M., and Price, R. C. (1983). The Late Proterozoic Ophiolite of Sol Hamed, NE Sudan. Precambrian Res. 19 (4), 385-411. doi:10.1016/0301-9268(83)90022-0

Fitzsimons, I. C. W. (2000). A Review of Tectonic Events in the East Antarctic Shield and Their Implications for Gondwana and Earlier Supercontinents. J. Afr. Earth Sci. 31 (1), 3-23. doi:10.1016/s0899-5362(00)00069-5

Fitzsimons, I. C. W. (2003). "Proterozoic Basement Provinces of Southern and Southwestern Australia, and Their Correlation with Antarctica," in Proterozoic East Gondwana: Supercontinent Assembly and Breakup. Editors M. Yoshida, B. F. Windley, and S. Dasgupta (London: Geological Society, Special Publications), 206, 93-130. doi:10.1144/gsl.sp.2003.206.01.07
Fritz, H., Abdelsalam, M., Ali, K. A., Bingen, B., Collins, A. S., Fowler, A. R., et al. (2013). Orogen Styles in the East African Orogen: A Review of the Neoproterozoic to Cambrian Tectonic Evolution. J. Afr. Earth Sci. 86, 65-106. doi:10.1016/j.jafrearsci.2013.06.004

Ganade de Araujo, C. E., Rubatto, D., Hermann, J., Cordani, U. G., Caby, R., and Basei, M. A. S. (2014). Ediacaran 2,500-Km-Long Synchronous Deep continental Subduction in the West Gondwana Orogen. Nat. Commun. 5, 5198. doi:10.1038/ncomms61988

Gasquet, D., Ennih, N., Liégeois, J.-P., Soulaimani, A., and Michard, A. (2008). "The Pan-African belt,". Continental Evolution: The Geology Of Morocco, Lectures Notes in Earth Sciences. Editor A. Michard, O. Saddiqi, A. Chalouan, and D. Frizon de Lamotte (Springer-Verlag Berlin Heidelberg publisher), 116, 33-64. doi:10.1007/978-3-540-77076-3_2

Gasquet, D., Levresse, G., Cheilletz, A., Azizi-Samir, M. R., and Mouttaqi, A. (2005). Contribution to a Geodynamic Reconstruction of the Anti-atlas (Morocco) during Pan-African Times with the Emphasis on Inversion Tectonics and Metallogenic Activity at the Precambrian-Cambrian Transition. Precambrian Res. 140, 157-182. doi:10.1016/j.precamres.2005. 06.009

Ghienne, J.-F., Boumendjel, K., Paris, F., Videt, B., Racheboeuf, P., and Salem, H. A. (2007). The Cambrian-Ordovician Succession in the Ougarta Range (Western Algeria, North Africa) and Interference of the Late Ordovician Glaciation on the Development of the Lower Palaeozoic Transgression on Northern Gondwana. Bull. Geosci. 82 (3), 183-214. doi:10.3140/bull.geosci. 2007.03.183

Ghienne, J.-F., Desrochers, A., Vandenbroucke, T. R. A., Achab, A., Asselin, E., Dabard, M.-P., et al. (2014). A Cenozoic-Style Scenario for the End-Ordovician Glaciation. Nat. Commun. 5 (4485), 9. doi:10.1038/ncomms5485

Goodge, J. W., Vervoort, J. D., Fanning, C. M., Brecke, D. M., Farmer, G. L., Williams, I. S., et al. (2008). A Positive Test of East Antarctica-Laurentia Juxtaposition within the Rodinia Supercontinent. Science 321 (5886), 235-240. doi:10.1126/science.1159189

Gray, D. R., Foster, D. A., Goscombe, B., Passchier, C. W., and Trouw, R. A. J. (2006). 40Ar/39Ar Thermochronology of the Pan-African Damara Orogen, Namibia, with Implications for Tectonothermal and Geodynamic Evolution. Precambrian Res. 150, 49-72. doi:10.1016/j. precamres.2006.07.003

Gray, D. R., Foster, D. A., Maas, R., Spaggiari, C. V., Gregory, R. T., Goscombe, B., et al. (2007). "Continental Growth and Recycling by Accretion of Deformed Turbidite Fans and Remnant Ocean Basins: Examples from Neoproterozoic and Phanerozoic Orogens,". The 4D Framework of Continental Crust. Editors R. D. HatcherJr., M. P. Carlson, J. H. McBride, and J. R. Martínez Catalán (Geological Society of America, Memoirs), 200, 63-92. doi:10.1130/2007. 1200(0510.1130/2007.1200(05)

Gray, D. R., Foster, D. A., Meert, J. G., Goscombe, B. D., Armstrong, R., Trouw, R. A. J., et al. (2008). "A Damara Orogen Perspective on the Assembly of Southwestern Gondwana,". West Gondwana Pre-cenozoic Correlations across the South Atlantic Region. Editors R. J. Pankhurst, R. A. J. Trouw, B. B. de Brito Neves, and M. J. de Wit (London: Geological Society, Special Publications), 294, 257-278. doi:10.1144/sp294.14

Grobys, J. W. G., Gohl, K., and Eagles, G. (2008). Quantitative Tectonic Reconstructions of Zealandia Based on Crustal Thickness Estimates. Geochem. Geophys. Geosyst. 9 (1), a-n. doi:10.1029/2007GC001691

Hanson, R. E. (2003). "Proterozoic Geochronology and Tectonic Evolution of Southern Africa,". Proterozoic East Gondwana: Supercontinent Assembly and Breakup. Editors M. Yoshida, B. E. Windley, and S. Dasgupta (London: Geological Society, Special Publcations), 206, 427-463. doi:10.1144/gsl.sp. 2003.206.01.20Geol. Soc. Lond. Spec. Publications

Harley, S. L., Fitzsimons, I. C. W., and Zhao, Y. (2013). Antarctica and Supercontinent Evolution: Historical Perspectives, Recent Advances and Unresolved Issues. Geol. Soc. Lond. Spec. Publications 383, 1-34. doi:10. $1144 / \mathrm{sp} 383.9$

Hochard, C. (2008). GIS and Geodatabases Application to Global Scale Plate Tectonics Modelling. Lausanne, Switzerland: Ph.D. thesis of the University of Lausanne, 174.

Hoffman, P. F. (1991). Did the Breakout of Laurentia Turn Gondwanaland InsideOut? Science 252 (5011), 1409-1412. doi:10.1126/science.252.5011.1409 
Immenhauser, A., Schreurs, G., Gnos, E., Oterdoom, H. W., and Hartmann, B. (2000). Late Palaeozoic to Neogene Geodynamic Evolution of the Northeastern Oman Margin. Geol. Mag. 137 (1), 1-18. doi:10.1017/s0016756800003526

Isseini, M. (2011). Croissance et différenciation crustales au Néoprotérozoïque; Exemple du domaine panafricain du Mayo Kebbi au Sud-Ouest du Tchad. Nancy, France: Ph.D. thesis of the University of Nancy, 345.

Johansson, A. (2009). Baltica, Amazonia and the SAMBA Connection-1000 Million Years of Neighbourhood during the Proterozoic? Precambrian Res. 175, 221-234. doi:10.1016/j.precamres.2009.09.011

Johansson, A. (2014). From Rodinia to Gondwana with the 'SAMBA' Model-A Distant View from Baltica towards Amazonia and beyond. Precambrian Res. 244, 226-235. doi:10.1016/j.precamres.2013.10.012

John, T., Schenk, V., Haase, K., Mezger, K., and Tembo, F. (2004). Timing and PT Evolution of Whiteschist Metamorphism in the Lufilian Arc - Zambezi Belt Orogen (Zambia): Implications for the Assembly of Gondwana. J. Geology 112, 70-90. doi:10.1086/379693

John, T., Schenk, V., Haase, K., Scherer, E., and Tembo, F. (2003). Evidence for a Neoproterozoic Ocean in South-central Africa from mid-oceanic-ridge-type Geochemical Signatures and Pressure-Temperature Estimates of Zambian Eclogites. Geol 31 (3), 243-246. doi:10.1130/0091-7613(2003)031<0243: efanoi $>2.0 . c 0 ; 2$

Johnson, P. R., Andresen, A., Collins, A. S., Fowler, A. R., Fritz, H., Ghebreab, W., et al. (2011). Late Cryogenian-Ediacaran History of the Arabian-Nubian Shield: A Review of Depositional, Plutonic, Structural, and Tectonic Events in the Closing Stages of the Northern East African Orogen. J. Afr. Earth Sci. 61, 167-232. doi:10.1016/j.jafrearsci.2011.07.003

Johnson, P. R., and Woldehaimanot, B. (2003). "Development of the ArabianNubian Shield: Perspectives on Accretion and Deformation in the Northern East African Orogen and the Assembly of Gondwana,". Proterozoic East Gondwana: Supercontinent Assembly and Breakup. Editors M. Yoshida, B. F. Windley, and S. Dasgupta (London: Geological Society, Special Publications), 206, 289-325. doi:10.1144/gsl.sp.2003.206.01.15

Kampunzu, A. B., and Cailteux, J. (1999). Tectonic Evolution of the Lufilian Arc (Central Africa Copper Belt) during Neoproterozoic Pan African Orogenesis. Gondwana Res. 2 (3), 401-421. doi:10.1016/s1342-937x(05)70279-3

Karlstrom, K. E., Bowring, S. A., Dehler, C. M., Knoll, A. H., Porter, S. M., Des Marais, D. J., et al. (2000). Chuar Group of the Grand Canyon: Record of breakup of Rodinia, associated change in the global carbon cycle, and ecosystem expansion by 740 Ma. Geology 28 (7), 619-622.

Kennedy, W. Q. (1964). The Structural Differentiation of Africa in the Pan-African $( \pm 500 \mathrm{My})$ Tectonic Episode, 8. Annual Reports of the Institute of African Geology of the University of Leeds, 48-49.

Key, R. M., Pitfield, P. E. J., Thomas, R. J., Goodenough, K. M., De Waele, B., Schofield, D. I., et al. (2011). "Polyphase Neoproterozoic Orogenesis within the East Africa-Antarctica Orogenic Belt in central and Northern Madagascar,". The Formation and Evolution of Africa: A Synopsis of $3.8 \mathrm{Ga}$ of Earth History. Editors D. J. J. van Hinsbergen, S. J. H. Buiter, T. H. Torsvik, C. Gaina, et al. (London: Geological Society, Special Publications), 357, 49-68. doi:10.1144/ sp357.4

Klein, E. L., and Moura, C. A. V. (2008). "São Luís Craton and Gurupi Belt (Brazil): Possible Links with the West African Craton and Surrounding Pan-African Belts,". West Gondwana Pre-cenozoic Correlations across the South Atlantic Region. Editors R. J. Pankhurst, R. A. J. Trouw, B. B. de Brito Neves, and M. J. de Wit (London: Geological Society, Special Publications), 294, 137-151. doi:10.1144/sp294.8

Kröner, A., and Brown, L. (2005). Structure, Composition and Evolution of the South Indian and Sri Lankan Granulite Terrains from Deep Seismic Profiling and Other Geophysical and Geological Investigations: A Legends Initiative. Gondwana Res. 8 (3), 317-335. doi:10.1016/s1342-937x(05)71138-2

Kroner, U., Stephan, T., Romer, R. L., and Roscher, M. (2020). Paleozoic Plate Kinematics during the Pannotia - Pangaea Supercontinent Cycle. Geol. Soc. Lond. Spec. Publications 503, 83-104.

Laux, J. H., Pimentel, M. M., Dantas, E. L., Armstrong, R., and Junges, S. L. (2005). Two Neoproterozoic Crustal Accretion Events in the Brasília belt, central Brazil. J. South Am. Earth Sci. 18, 183-198. doi:10.1016/j.jsames. 2004.09.003

Le Métour, J., Michel, J.-C., Béchennec, F., Platel, J.-P., and Roger, J. (1995). Geology and mineral Wealth of the Sultanate of Oman, Muscat, Oman. France:
Ministry of Petroleum and Minerals, Directorate General of Minerals, Sultanate of Oman, Muscat and Bureau de Recherches Géologiques et Minières, 285.

Leat, P. T., Dean, A. A., Millar, I. L., Kelley, S. P., Vaughan, A. P. M., and Riley, T. R. (2005). "Lithospheric Mantle Domains beneath Antarctica,". Terrane Processes at the Margins of Gondwana. Editors A. Vaughan, P. Leat, and R. Pankhurst (London: Geological Society, Special Publications), 246, 359-380. doi:10.1144/ gsl.sp.2005.246.01.15Geol. Soc. Lond. Spec. Publications

Leprêtre, R. (2015). Evolution phanérozoïque du Craton Ouest Africain et de ses bordures Nord et Ouest. Ph.D. thesis. Paris XI, France: of the University Paris-Sud, 422. Availableat: https://tel.archives-ouvertes.fr/tel-01155163/file/ VD2_LEPRETRE_REMI_08042015.pdf.

Li, Z.-X., Zhang, L., and Powell, C. M. (1995). South China in Rodinia: Part of the Missing Link between Australia-East Antarctica and Laurentia? Geol 23, 407-410. doi:10.1130/0091-7613(1995)023<0407:scirpo >2.3.co;2

Li, Z., Li, X. H., Kinny, P. D., Wang, J., Zhang, S., and Zhou, H. (2003). Geochronology of Neoproterozoic Syn-Rift Magmatism in the Yangtze Craton, South China and Correlations with Other Continents: Evidence for a Mantle Superplume that Broke up Rodinia. Precambrian Res. 122, 85-109. doi:10.1016/s0301-9268(02)00208-5

Li, Z. X., Bogdanova, S. V., Collins, A. S., Davidson, A., De Waele, B., Ernst, R. E., et al. (2008). Assembly, Configuration, and Break-Up History of Rodinia: A Synthesis. Precambrian Res. 160, 179-210. doi:10.1016/j.precamres.2007.04.021

Li, Z. X., and Powell, C. M. (2001). An Outline of the Palaeogeographic Evolution of the Australasian Region since the Beginning of the Neoproterozoic. EarthScience Rev. 53, 237-277. doi:10.1016/s0012-8252(00)00021-0

Liégeois, J.-P., Abdelsalam, M. G., Ennih, N., and Ouabadi, A. (2013). Metacraton: Nature, Genesis and Behavior. Gondwana Res. 23, 220-237. doi:10.1016/j.gr. 2012.02.016

Liégeois, J. P., Black, R., Navez, J., and Latouche, L. (1994). Early and Late PanAfrican Orogenies in the Air Assembly of Terranes (Tuareg Shield, Niger). Precambrian Res. 67, 59-88. doi:10.1016/0301-9268(94)90005-1

Liégeois, J. P., Latouche, L., Boughrara, M., Navez, J., and Guiraud, M. (2003). The LATEA Metacraton (Central Hoggar, Tuareg Shield, Algeria): Behaviour of an Old Passive Margin during the Pan-African Orogeny. J. Afr. Earth Sci. 37, 161-190. doi:10.1016/j.jafrearsci.2003.05.004

Louis, P. (1970). Contribution géophysique à la connaissance géologique du bassin du lac Tchad, Mémoires OrstomOrstom ParisFrance. 42, 355.

Maboko, M. A. H., and Nakamura, E. (2002). Isotopic Dating of Neoproterozoic Crustal Growth in the Usambara Mountains of Northeastern Tanzania: Evidence for Coeval Crust Formation in the Mozambique Belt and the Arabian-Nubian Shield. Precambrian Res. 113, 227-242. doi:10.1016/s03019268(01)00213-3

Maus, S., Barckhausen, U., Berkenbosch, H., Bournas, N., Brozena, J., Childers, V., et al. (2009). EMAG2: A 2-arc Min Resolution Earth Magnetic Anomaly Grid Compiled from Satellite, Airborne, and marine Magnetic Measurements. Geochem. Geophys. Geosyst. 10 (8), a-n. doi:10.1029/2009gc002471

McMenamin, M. A. S., and McMenamin, D. L. S. (1990). The Emergence of Animals: The Cambrian Breakthrough. New York: Columbia University Press. doi: $10.7312 / \mathrm{mcme} 93416$

Meert, J. G. (2003). A Synopsis of Events Related to the Assembly of Eastern Gondwana. Tectonophysics 362, 1-40. doi:10.1016/s0040-1951(02)00629-7

Meert, J. G., and Powell, C. McA. (2001). Assembly and break-up of Rodinia: Introduction to the special volume. Precambrian Res. 110 (1-4), 1-8.

Meert, J. G., and Torsvik, T. H. (2003). The Making and Unmaking of a Supercontinent: Rodinia Revisited. Tectonophysics 375 (1), 261-288. doi:10. 1016/s0040-1951(03)00342-1

Meert, J. G. (2012). What's in a Name? the Columbia (Paleopangaea/Nuna) Supercontinent. Gondwana Res. 21, 987-993. doi:10.1016/j.gr.2011.12.002

Merdith, A. S., Collins, A. S., Williams, S. E., Pisarevsky, S., Foden, J. D., Archibald, D. B., et al. (2017). A full-plate global reconstruction of the Neoproterozoic. Gondwana Res. 50, 84-134.

Moulin, M. (2003). Etude géologique et géophysique des marges continentales passives : Exemple du Zaire et de l'Angola. Brest, France: Ph.D. thesis of the University of Bretagne Occidentale, 360.

Murphy, J. B., Nance, R. D., Cawood, P. A., Collins, W. J., Dan, W., Doucet, L. S., et al. (2020). Pannotia: In Defence of its Existence and Geodynamic Significance, Geol. Soc. Lond. Spec. Publications, 503., SP503-2020. doi:10. 1144/SP503-2020-96 
Myrow, P. M., Hughes, N. C., McKenzie, N. R., Pelgay, P., Thomson, T. J., Haddad, E. E., et al. (2016). Cambrian-Ordovician Orogenesis in Himalayan Equatorial Gondwana. Geol. Soc. America Bull. 128 (11/12), 1679-1695. doi:10.1130/ b31507.1

Naba, S. (2007). Propriétés magnétiques et caractèrs structuraux des granites $d u$ Burkina Faso oriental (Craton Ouest Africain, $2.2-2.0 \mathrm{Ga}$ ) : implications géodynamiques. France: Ph.D. thesis of the University of Toulouse, 174. Availableat: http://thesesups.ups-tlse.fr/814/1/Naba_Seta.pdf.

Nance, R. D., Murphy, J. B., and Santosh, M. (2014). The Supercontinent Cycle: A Retrospective Essay. Gondwana Res. 25 (1), 4-29. doi:10.1016/j.gr.2012.12.026

Nance, R. D., and Murphy, J. B. (2018). Supercontinents and the Case for Pannotia, Geol. Soc. Lond. Spec. Publications, 470. 65-86. doi:10.1144/sp470.5

Neves, B. B. d. B., Neto, M. d. C. C., and Fuck, R. A. (1999). From Rodinia to Western Gondwana: An Approach to the Brasiliano-Pan African Cycle and Orogenic Collage. Episodes 22 (3), 155-166. doi:10.18814/epiiugs/1999/ v22i3/002

Oriolo, S., Oyhantçabal, P., Wemmer, K., and Siegesmund, S. (2017). Contemporaneous Assembly of Western Gondwana and Final Rodinia Break-Up: Implications for the Supercontinent Cycle. Geosci. Front. 8, 1431-1445. doi:10.1016/j.gsf.2017.01.009

Oriolo, S., Schulz, B., Geuna, S., González, P. D., Otamendi, J. E., Sláma, J., et al. (2021). Early Paleozoic Accretionary Orogens along the Western Gondwana Margin. Geosci. Front. 12, 109-130. doi:10.1016/j.gsf.2020.07.001

Ouabego Kourtene, M. (2013). Contribution à l'étude de la chaîne panafricaine des Oubanguides en République Centrafricaine. Aix-Marseille, France: Ph.D. thesis of the University of Aix-Marseille, 206.

Penaye, J., Kröner, A., Toteu, S. F., van Schmus, W. R., and Doumnang, J.-C. (2006). Evolution of the Mayo Kebbi Region as Revealed by Zircon Dating: An Early (Ca. 740Ma) Pan-African Magmatic Arc in Southwestern Chad. J. Afr. Earth Sci. 44, 530-542. doi:10.1016/j.jafrearsci.2005.11.018

Pimentel, M. M., Fuck, R. A., Jost, H., Ferreira Filho, C. F., and de Araújo, S. M. (2000). The Basement of the Brasília Fold belt and the Goiás Magmatic Arc, Tectonic Evolution of South America; 31st International Geologcial Congress, Rio de Janeiro. Editors U. G. Cordani, E. J. Milani, A. Thomaz Filho, and D. A. Campos, 195-229.

Pimentel, M. M., Rodrigues, J. B., DellaGiustina, M. E. S., Junges, S., Matteini, M., and Armstrong, R. (2011). The Tectonic Evolution of the Neoproterozoic Brasília Belt, central Brazil, Based on SHRIMP and LA-ICPMS U-Pb Sedimentary Provenance Data: A Review. J. South Am. Earth Sci. 31, 345-357. doi:10.1016/j.jsames.2011.02.011

Piper, J. D. A. (2010). Palaeopangaea in Meso-Neoproterozoic Times: The Palaeomagnetic Evidence and Implications to continental Integrity, Supercontinent Form and Eocambrian Break-Up. J. Geodynamics 50, 191-223. doi:10.1016/j.jog.2010.04.004

Piper, J. D. A. (1976). Palæomagnetic Evidence for a Proterozoic Super-continent. Philosophical Trans. R. Soc. Lond. Ser. A, Math. Phys. Sci. 280 (1298), 469-490.

Pisarevsky, S. A., Wingate, M. T. D., Powell, C. M., Johnson, S., and Evans, D. A. D. (2003). "Models of Rodinia Assembly and Fragmentation,". Proterozoic East Gondwana : Supercontinent Assembly and Breakup. Editors M. Yoshida, B. F. Windley, and S. Dasgupta (London: Geological Society, Special Publications), 206, 35-55. doi:10.1144/gsl.sp.2003.206.01.04 Geol. Soc. Lond. Spec. Publications

Poudjom Djomani, Y. H. (1994). Apport de la gravimétrie à l'étude de la lithosphere continentale et implications géodynamiques. Etude d'un bombement intraplaque : Le massif de l'Adamaoua (Cameroun). Orsay, France: Ph.D. thesis of the University of Paris-Sud, 313.

Powell, C. Mc. A., and Pisarevsky, S. (2001). Rodinia to Gondwanaland: Growth of the Pacific Ocean and Destruction of Het Mozambique and Brazilide Oceans, GSA Conference, Earth System Processes - Global Meeting Abstract, June 24-28, 2001. Available at: https:/gsa.confex.com/gsa/2001ESP/webprogram/ Paper8026.html.

Powell, C. M., and Young, G. M. (1995). Are Neoproterozoic Glacial Deposits Preserved on the Margins of Laurentia Related to the Fragmentation of Two Supercontinents? Comment and Reply. Geol. 23 (11), 1053-1055. doi:10.1130/ 0091-7613(1995)023<1053:angdpo>2.3.co;2

Raharimahefa, T., and Kusky, T. M. (2006). Structural and Remote Sensing Studies of the Southern Betsimisaraka Suture, Madagascar. Gondwana Res. 10, 186-197. doi:10.1016/j.gr.2005.11.022
Ramos, V. A. (2004). Cuyania, an Exotic Block to Gondwana: Review of a Historical success and the Present Problems. Gondwana Res. 7 (4), 1009-1026. doi:10.1016/s1342-937x(05)71081-9

Ramos, V. A. (2008). Patagonia: A Paleozoic Continent Adrift? J. South Am. Earth Sci. 26, 235-251. doi:10.1016/j.jsames.2008.06.002

Ramos, V. A. (2010). The Grenville-Age Basement of the Andes. J. South Am. Earth Sci. 29, 77-91. doi:10.1016/j.jsames.2009.09.004

Rapela, C. W., Fanning, C. M., Casquet, C., Pankhurst, R. J., Spalletti, L., Poiré, D., et al. (2011). The Rio de la Plata craton and the adjoining Pan-African/ brasiliano terranes: Their origins and incorporation into south-west Gondwana. Gondwana Res. 20, 673-690. doi:10.1016/j.gr.2011.05.001

Rapela, C. W., Pankhurst, R. J., Casquet, C., Fanning, C. M., Baldo, E. G., González-Casado, J. M., et al. (2007). The Río de la Plata craton and the assembly of SW Gondwana. Earth-Science Rev. 83, 49-82. doi:10.1016/j. earscirev.2007.03.004

Rodrigues, J. B., Pimentel, M. M., Buhn, B., Matteini, M., Dardenne, M. A., Alvarenga, C. J. S., et al. (2012). Provenance of the Vazante Group: New $\mathrm{U}-\mathrm{Pb}, \mathrm{Sm}-\mathrm{Nd}$, Lu-Hf Isotopic Data and Implications for the Tectonic Evolution of the Neoproterozoic Brasília Belt. Gondwana Res. 21, 439-450. doi:10.1016/j. gr.2011.07.017

Rodrigues, J. B., Pimentel, M. M., Dardenne, M. A., and Armstrong, R. A. (2010). Age, Provenance and Tectonic Setting of the Canastra and Ibiá Groups (Brasilia Belt, Brazil): Implications for the Age of a Neoproterozoic Glacial Event in central Brazil. J. South Am. Earth Sci. 29, 512-521. doi:10.1016/j.jsames.2009.08.008

Ross, M. I., and Scotese, C. R. (1988). A hierarchical tectonic model of the Gulf of Mexico and Caribbean region. Tectonophysics 155, 139-168.

Roy, A. B., and Purohit, R. (2018). "The Himalayas: Evolution through Collision," in Indian Shield; Precambrian Evolution and Phanerozoic Reconstitution. Editors A. B. Roy and R. Purohit (Elsevier), 311-327. doi:10.1016/B978-012-809839-4.00018-7

Saki, A. (2010). Proto-Tethyan Remnants in Northwest Iran: Geochemistry of the Gneisses and Metapelitic Rocks. Gondwana Res. 17, 704-714. doi:10.1016/j.gr. 2009.08.008

Santos, J. O. S., Chernicoff, C. J., Zappettini, E. O., McNaughton, N. J., and Hartmann, L. A. (2019). Large geographic and temporal extensions of the Río de la Plata Craton, South America, and its metacratonic eastern margin. Int. Geology. Rev. 61 (1), 56-85. doi:10.1080/00206814.2017.1405747

Santosh, M., Maruyama, S., and Sato, K. (2009). Anatomy of a Cambrian Suture in Gondwana: Pacific-type Orogeny in Southern India? Gondwana Res. 16, 321-341. doi:10.1016/j.gr.2008.12.012

Scotese, C. R., and Elling, R. (2017). Plate Tectonic Evolution during the Last 1.0 Billion Years: The Movie. Conference at the William Smith Meeting 2017: Plate Tectonics at 50, September 29-October 1, 2017 (Geological Society of London. ). Available at: https://www.youtube.com/watch?v=CnVGFv-1Wqc\&feature=youtu.be (Accessed October 50, 2017).

Scotese, C. R. (2009). Late Proterozoic Plate Tectonics and Palaeogeography: a Tale of Two Supercontinents, Rodinia and Pannotia, Geol. Soc. Lond. Spec. Publications, 326. 67-83. doi:10.1144/sp326.4

Scotese, C. R. (2016). Tutorial: PALEOMAP paleoAtlas for GPlates and the paleoData plotter program. Technical Report, 56. Available at: https://www. earthbyte.org/paleomap-paleoatlas-for-gplates/.

Şengör, A. M. C., and Natal'in, B. (2007). "Eduard Suess and the Altaids: What Is in a Name?," in Magmatism And Metallogeny Of the Altai And Adjacent Large Igneous Provinces With an Introductory Essay On the Altaids. Essay in IAGOD Guidebook Series 16, Part C. Editors R. Seltmann, A. Borisenko, and G. Fedoseev (London: Cercams/Nhm), 185-294.

Seton, M., Müller, R. D., Zahirovic, S., Gaina, C., Torsvik, T., and Shephard, G. (2012). Global continental and ocean basin reconstructions since $200 \mathrm{Ma}$. Earth Sci. Rev. 113, 212-270.

Shan-Shan, L., Santosh, M., Indu, G., Shaji, E., and Tsunogae, T. (2017). Detrital Zircon Geochronology of Quartzites from the Southern Madurai Block, India: Implications for Gondwana Reconstruction. Geosci. Front. 8, 851-867.

Sharma, K. (1998). Geological and Tectonic Evolution of the Himalaya before and after the India-Asia Collision. Proc. Indian Academia Sci. (Earth Planet. Sciences) 107 (4), 265-282.

Siegesmund, S., Stipp Basei, M. A., Oyhantçabal, P., and Oiolo, S. (Editors) (2018). Geology of Southwest Gondwana. Cham: Springer, Regional Geology Reviews, 688. 
Sommer, H., Kröner, A., Hauzenberger, C., and Muhongo, S. (2005). Reworking of Archaean and Palaeoproterozoic Crust in the Mozambique belt of central Tanzania as Documented by SHRIMP Zircon Geochronology. J. Afr. Earth Sci. 43, 447-463. doi:10.1016/j.jafrearsci.2005.09.005

Stampfli, G. M., and Borel, G. D. (2002). A Plate Tectonic Model for the Paleozoic and Mesozoic Constrained by Dynamic Plate Boundaries and Restored Synthetic Oceanic Isochrons. Earth Planet. Sci. Lett. 196, 17-33. doi:10. 1016/s0012-821x(01)00588-x

Stampfli, G. M., Hochard, C., Vérard, C., Wilhem, C., and vonRaumer, J. (2013). The Formation of Pangea. Tectonophysics 593, 1-19. doi:10.1016/j.tecto.2013. 02.037

Stephan, T., Kroner, U., Romer, R. L., and Rösel, D. (2019). From a Bipartite Gondwanan Shelf to an Arcuate Variscan belt: The Early Paleozoic Evolution of Northern Peri-Gondwana. Earth-Science Rev. 192, 491-512. doi:10.1016/j. earscirev.2019.03.012

Stern, R. J., and Johnson, P. (2010). Continental Lithosphere of the Arabian Plate: A Geologic, Petrologic, and Geophysical Synthesis. Earth-Science Rev. 101, 29-67. doi:10.1016/j.earscirev.2010.01.002

Stewart, J. H. (2009). Reconstructing Rodinia by fitting Neoproterozoic continental margins. U.S. Geological Survey Open-File Report 2009 -1191, 98. Available at: http://pubs.usgs.gov/of/2009/1191/.

Stoeser, D. B., and Frost, C. D. (2006). Nd, Pb, Sr, and O Isotopic Characterization of Saudi Arabian Shield Terranes. Chem. Geology. 226, 163-188. doi:10.1016/j. chemgeo.2005.09.019

Stump, E. (1987). "Construction of the Pacific Margin of Gondwana during the Pannotios Cycle,". Gondwana Six: Structure, Tectonics and Geophysics. Editor G. D. McKenzie (American Geophysical Union Monograph), 40, 77-87.

Swanson-Hysell, N. L., Maloof, A. C., Kirschvink, J. L., Evans, D. A. D., Halverson, G. P., and Hurtgen, M. T. (2012). Constraints on Neoproterozoic Paleogeography and Paleozoic Orogenesis from Paleomagnetic Records of the Bitter Springs Formation, Amadeus Basin, central Australia. Am. J. Sci. 312, 817-884. doi:10.2475/08.2012.01

Tack, L., Wingate, M. T. D., Liégeois, J.-P., Fernandez-Alonso, M., and Deblond, A. (2001). Early Neoproterozoic Magmatism (1000â $€$ "910 Ma) of the Zadinian and Mayumbian Groups (Bas-Congo): Onset of Rodinia Rifting at the Western Edge of the Congo Craton. Precambrian Res. 110, 277-306. doi:10.1016/s03019268(01)00192-9

Tairou, M. S., Affaton, P., Anum, S., and Fleury, T. J. (2012). Pan-African paleostresses and reactivation of the Eburnean Basement complex in Southeast Ghana (West Africa). J. Geol. Res. 2012, 938927.

Tapley, B., Ries, J., Bettadpur, S., Chambers, D., Cheng, M., Condi, F., et al. (2005). GGM02 - an Improved Earth Gravity Field Model from GRACE. J. Geodesy 79, 467-478. doi:10.1007/s00190-005-0480-z

Thomas, R. J., Jacobs, J., Elburg, M. A., Mruma, A., Kamihanda, G., Kankila, A., et al. (2019). New U-Pb-Hf Zircon Isotope Data for the Paleoproterozoic Ubendian belt in the Chimala Area, SW Tanzania. Geosci. Front. 10, 1993-2006. doi:10.1016/j.gsf.2018.05.010

Tohver, E., Cawood, P. A., Rossello, E. A., and Jourdan, F. (2012). Closure of the Clymene Ocean and formation of West Gondwana in the Cambrian: Evidence from the Sierras Australes of the southernmost Rio de la Plata craton, Argentina. Gondwana Res. 21, 394-405. doi:10.1016/j.gr.2011.04.001

Tohver, E., D'Agrella-Filho, M. S., and Trindade, R. I. F. (2006). Paleomagnetic Record of Africa and South America for the 1200-500Ma Interval, and Evaluation of Rodinia and Gondwana Assemblies. Precambrian Res. 147, 193-222. doi:10.1016/j.precamres.2006.01.015

Torsvik, T. H., and Rehnström, E. F. (2003). The Tornquist Sea and BalticaAvalonia Docking. Tectonophysics 362, 67-82. doi:10.1016/s0040-1951(02) 00631-5

Torsvik, T. H., Van der Voo, R., Preeden, U., Mac Niocaill, C., Steinberger, B., Doubrovine, P. V., et al. (2012). Phanerozoic Polar Wander, Palaeogeography and Dynamics. Earth-Science Rev. 114, 325-368. doi:10.1016/j.earscirev.2012. 06.007

Torsvik, T., Smethurst, M., Meert, J., Vandervoo, R., McKerrow, W., Brasier, M., et al. (1996). Continental Break-Up and Collision in the Neoproterozoic and Palaeozoic - A Tale of Baltica and Laurentia. Earth-Science Rev. 40, 229-258. doi:10.1016/0012-8252(96)00008-6

Trouw, R. A. J., Peternel, R., Ribeiro, A., Heilbron, M., Vinagre, R., Duffles, P., et al. (2013). A New Interpretation for the Interference Zone between the Southern
Brasilia belt and the central Ribeira belt, SE Brazil. J. South Am. Earth Sci. 48, 43-57. doi:10.1016/j.jsames.2013.07.012

Tucker, R. D., Roig, J. Y., Macey, P. H., Delor, C., Amelin, Y., Armstrong, R. A., et al. (2011). A New Geological Framework for South-central Madagascar, and its Relevance to the "Out-Of-Africa" Hypothesis. Precambrian Res. 185, 109-130. doi:10.1016/j.precamres.2010.12.008

Valentine, J. W., and Moores, E. M. (1970). Plate-tectonic Regulation of Faunal Diversity and Sea Level: A Model. Nature 228, 657-659. doi:10.1038/228657a0 Valeriano, C. M., Pimentel, M. M., Heilbron, M., Almeida, J. C. H., and Trouw, R. A. J. (2008). "Tectonic Evolution of the Brasília Belt, Central Brazil, and Early Assembly of Gondwana,". West Gondwana Pre-cenozoic Correlations across the South Atlantic Region. Editors R. J. Pankhurst, R. A. J. Trouw, B. B. de Brito Neves, and M. J. de Wit (London: Geological Society, Special Publications), 294, 197-210. doi:10.1144/sp294.11

van Staal, C. R., Barr, S. M., and Murphy, J. B. (2012). Provenance and Tectonic Evolution of Ganderia: Constraints on the Evolution of the Iapetus and Rheic Oceans. Geology 40, 987-990. doi:10.1130/g33302.1

Vérard, C., Hochard, C., Baumgartner, P. O., Stampfli, G. M., and Liu, M. (2015a). 3D Palaeogeographic Reconstructions of the Phanerozoic versus Sea-Level and Sr-Ratio Variations. J. Palaeogeogr. 4 (1), 64-84. doi:10.3724/sp.j.1261.2015. 00068

Vérard, C., Hochard, C., Baumgartner, P. O., Stampfli, G. M., and Liu, M. (2015b). Geodynamic Evolution of the Earth over the Phanerozoic: Plate Tectonic Activity and Palaeoclimatic Indicators. J. Palaeogeogr. 4 (2), 167-188. doi:10.3724/sp.j.1261.2015.00072

Vérard, C., Hochard, C., and Stampfli, G. (2012). Non-random Distribution of Euler Poles: Is Plate Tectonics Subject to Rotational Effects? Terra Nova 24, 467-476. doi:10.1111/j.1365-3121.2012.01085.x

Vérard, C. (2004). Palcoozoic Palcoomagnetism of southeastern Australia: Implications for the APW Path of Gondwana. Munich, Germany: Ph.D. thesis of the Ludwig-Maximilians-Universität München, 217.

Vérard, C. (2019a). Panalesis: towards Global Synthetic Palaeogeographies Using Integration and Coupling of Manifold Models. Geol. Mag. 156 (2), 320-330. doi:10.1017/S0016756817001042

Vérard, C. (2019b). Plate Tectonic Modelling: Review and Perspectives. Geol. Mag. 156 (2), 208-241. doi:10.1017/S0016756817001030

Vérard, C., and Stampfli, G. (2013a). Geodynamic Reconstructions of the Australides-1: Palaeozoic. Geosciences 3, 311-330. doi:10.3390/ geosciences 3020311

Vérard, C., and Stampfli, G. (2013b). Geodynamic Reconstructions of the Australides-2: Mesozoic-Cainozoic. Geosciences 3, 331-353. doi:10.3390/ geosciences 3020331

Vérard, C., and Veizer, J. (2019). On Plate Tectonics and Ocean Temperatures. Geology 47, 881-885. doi:10.1130/g46376.1

Villeneuve, M., Bellon, H., El Archi, A., Sahabi, M., Rehault, J.-P., Olivet, J.-L., et al. (2006). Événements Panafricains Dans l'Adrar Souttouf (Sahara Marocain). Comptes Rendus Geosci. 338, 359-367. doi:10.1016/j.crte.2006.02.008

Villeneuve, M., El Archi, A., and Nzamba, J. (2010). Les chaînes de la marge occidentale du Craton Ouest-Africain, modèles géodynamiques. Comptes Rendus Geosci. 342, 1-10. doi:10.1016/j.crte.2009.12.002

Villeneuve, M. (1984). Etude géologique de la bordure sud-ouest du craton ouestafricain. La suture pan-africaine et l'évolution des bassins sédimentaires protérozoïques et paléozoïques de la marge $N W$ du continent de Gondwana. Aix-Marseille, France: Ph.D. thesis (thèse d'État) of the University of AixMarseille III, 551.

Villeneuve, M., Gärtner, A., Youbi, N., El Archi, A., Vernhet, E., Rjimati, E.-C., et al. (2015). The Southern and central Parts of the "Souttoufide" belt, Northwest Africa. J. Afr. Earth Sci. 112 (B), 451-470. doi:10.1016/j. jafrearsci.2015.04.016

Villeneuve, M. (2005). Paleozoic Basins in West Africa and the Mauritanide Thrust belt. J. Afr. Earth Sci. 43, 166-195. doi:10.1016/j.jafrearsci.2005.07.012

von Raumer, J. F., Bussy, F., Schaltegger, U., Schulz, b., and Stampfli, G. M. (2012). Pre-Mesozoic Alpine Basements-Their Place in the European Paleozoic Framework, Geol. Soc. America Bull., 125., 89-108. doi:10.1130/B30654.1

von Raumer, J. F., Stampfli, G. M., Arenas, R., and Sánchez Martínez, S. (2015). Ediacaran to Cambrian Oceanic Rocks of the Gondwana Margin and Their Tectonic Interpretation. Int. J. Earth Sci. (Geol Rundsch) 104, 1107-1121. doi:10.1007/s00531-015-1142-x 
von Raumer, J. F., and Stampfli, G. M. (2008). The Birth of the Rheic Ocean - Early Palaeozoic Subsidence Patterns and Subsequent Tectonic Plate Scenarios. Tectonophysics 461, 9-20. doi:10.1016/j. tecto.2008.04.012

Weil, A. B., Van der Voo, R., Mac Niocaill, C., and Meert, J. G. (1998). The Proterozoic Supercontinent Rodinia: Paleomagnetically Derived Reconstructions for 1100 to 800 Ma. Earth Planet. Sci. Lett. 154, 13-24. doi:10.1016/s0012-821x(97)00127-1

Wilhem, C. (2010). Plate Tectonics of the Altaids. Lausanne, Switzerland: Ph.D. thesis of the University of Lausanne, 347.

Wilhem, C., Windley, B. F., and Stampfli, G. M. (2012). The Altaids of Central Asia: A Tectonic and Evolutionary Innovative Review. Earth-Science Rev. 113, 303-341. doi:10.1016/j.earscirev.2012.04.001

Williams, H. R., and Culver, S. J. (1982). The Rokelides of West Africa - PanAfrican Aulacogen or Back-Arc basin? Precambrian Res. 18 (3), 261-273. doi:10.1016/0301-9268(82)90013-4

Wingate, M. T. D., Pisarevsky, S. A., and Evans, D. A. D. (2002). Rodinia Connections between Australia and Laurentia: No SwEat, No AusWUS? Terra Nova 14, 121-128. doi:10.1046/j.1365-3121.2002. 00401.x
Yoshida, M., and Santosh, M. (2011). Supercontinents, Mantle Dynamics and Plate Tectonics: A Perspective Based on Conceptual vs. Numerical Models. EarthScience Rev. 105, 1-24. doi:10.1016/j.earscirev.2010.12.002

Young, G. M. (1995). Are Neoproterozoic Glacial Deposits Preserved on the Margins of Laurentia Related to the Fragmentation of Two Supercontinents? Geol. 23 (2), 153-156. doi:10.1130/0091-7613(1995)023<0153:angdpo >2.3.co;2

Žák, J., and Sláma, J. (2018). How Far Did the Cadomian 'terranes' Travel from Gondwana during Early Palaeozoic? A Critical Reappraisal Based on Detrital Zircon Geochronology. Int. Geology Rev. 60 (3), 319-338.

Conflict of Interest: The author declares that the research was conducted in the absence of any commercial or financial relationships that could be construed as a potential conflict of interest.

Copyright (C) 2021 Vérard. This is an open-access article distributed under the terms of the Creative Commons Attribution License (CC BY). The use, distribution or reproduction in other forums is permitted, provided the original author(s) and the copyright owner(s) are credited and that the original publication in this journal is cited, in accordance with accepted academic practice. No use, distribution or reproduction is permitted which does not comply with these terms. 